\title{
PREMA SOCIOLOGIZACIJI LIJENOSTI - KONCEPTUALNE KLARIFIKACIJE I PRELIMINARNI EMPIRIJSKI UVIDI
}

\author{
Luka Canjek i Krešimir Žažar
}

\author{
Naftaplinska 24c, 10312 Kloštar Ivanić \\ e-mail: lcanjek@gmail.com
}

\begin{abstract}
Sažetak
Temeljna je intencija ovog rada problematizirati "lijenost" kao esencijalno društveni fenomen. Lijenost se uobičajeno smatra individualnim atributom pojedinca te se kao kakva, ponajprije preko koncepta prokrastinacije, tematizira u okvirima psihologije te medicinske znanosti. Krucijalno stanovisste koje se nastoji razraditi u članku jest da je lijenost inherentno društvena pojava jer njezina definicija te, posljedično, kategorizacija odredenog individuuma kao "lijenog" ovisi o sociokulturnom kontekstu koji odredeni oblik socijalne akcije, uputnije rečeno njezin izostanak, etiketira kao lijenost pri tom iskazujući mahom negativne konotacije. U radu se ukazuje na sociokulturnu pozadinu definiranja lijenosti pri čemu se ističu njezini religijski korijeni te vezanost koncepta lijenosti uz specificno poimanje vremena. Osobito se problematizira kontekst modernih kapitalističkih društava čija se kulturna matrica pokazuje podesnom za kategoriziranje određenog ponašanja kao lijenog kao i relacija medija te specifičnih životnih stilova naspram kategorije lijenosti. Na konceptualnoj ravni raspetljava se odnos izmedu koncepata lijenosti i prokrastinacije, s jedne ali i lijenosti naspram dokolice, s druge strane.

U drugom, empirijskom, dijelu rada daje se pregled eksplorativnog / izvidajnog istraživanja koje je 2018. metodom polustrukturiranog intervjua provedeno na prigodnom uzorku $(N=15)$ studenatalica Filozofskog fakulteta Sveučilišta u Zagrebu. Unatoč izvjesnim epistemološkim ograničenjima, nalazi istraživanja ukazuju na poimanja različitih aspekata i dimenzija lijenosti u ciljanoj populaciji, a što reprezentira robusnu osnovicu za daljnja potrebna podrobnija (teorijska i empirijska) sociološka istraživanja ovoga relevantnog sociokulturnog fenomena.
\end{abstract}

Ključne riječi: koncept lijenosti, sociološki pristup, sociokulturna matrica, moderna kapitalistička društva, utjecaj medija

\section{UVOD}

Termin „lijenost“ i njegove izvedenice nerijetko se mogu susresti u različitim tipovima diskursa u najširem spektru situacija. Svaki pojedinac izgledno može evocirati određene slučajeve kada je naišao na reakcije ili komentare, upozorenja pa i imperative poput „ne budi lijen!“, „nemoj biti lijenčina!“ i tomu slično. Takav tip ekspresija koje se mogu trasirati još od vremena primarne socijalizacije, preko školskog sustava i drugih ponajprije odgojnih ustanova, rezolutno iskazuje da određen tip postupaka koji se ponaj- 
prije manifestira u izostanku preferiranih korisnih radnji ili pak u odlaganju izvršenja preferiranih akcija, najčešće izvjesnih radnih zadataka, nije prihvatljiv te može naići na različite stupnjeve osuđivanja - od generalnog iskazivanja nenaklonosti osobe koja iskazuje „lijenost“ do formalnog sankcioniranja u obličju negativnih ocjena u školi ili smanjivanja dohotka odnosno drugih sankcija ukoliko je riječ o radnom odnosu. U slučaju opetovanja čina lijenosti određenu se osobu počinje etiketirati kao „lijenu“ što smanjuje njezin kredibilitet, pouzdanost, društvenu reputacija što se može itekako negativno odraziti na diferentne aspekte kvalitete (društvenog) života. Obilježje „lijenosti“ tako tendira postati odrednica nečije osobnosti. Taj individualni aspekt lijenosti u znanstvenom se diskursu manifestira kroz psihologijsko ili pak kliničko razmatranje lijenosti koje u pravilu izučava ili podvrgava osobe koje iskazuju atribute „lijenosti terapeutskim postupcima“" Iz psihologijskog i medicinskog rakursa lijenost se, dakle, smatra individualnom kategorijom (Senécal i sur., 1995).

Naša je pak intencija ovdje razotkriti lijenost kao suštinski društveni fenomen odnosno konstrukt. Definicije lijenosti te njezine manifestacije esencijalno su ovisne o društvenom okruženju koji određen tip radnji određuje takvima te imaju duboku sociokulturnu ukorijenjenost. Ovaj je rad inicijalni korak prema sociologizaciji problematiziranja lijenosti. Taj poduhvat započet ćemo tematiziranjem koncepta lijenosti u relaciji spram srodnog koncepta prokrastinacije ${ }^{1}$, a nakon toga ukazat ćemo na sociokulturnu ukotvljenost lijenosti uz poseban osvrt na tretiranja lijenosti u pojedinim religijskim sustavima. Pregledni teorijsko-konceptualni dio rada zaokružit ćemo raspravom o statusu lijenosti u modernim kapitalističkim društvima. Sljedeća sekvenca rada donosi pregled najvažnijih nalaza empirijskog istraživanja provedenog metodom intervjua na prigodnom uzorku studenata/ica zagrebačkoga Filozofskog fakulteta. Kroz istraživačko izvješće razvidnim postaju poimanja različitih aspekata lijenosti, s posebnim naglaskom na njezine društvene korelate. Unatoč izvjesnim manjkavostima istraživanja, ono daje solidnu osnovicu za daljnja sociološka ispitivanja lijenosti.

\section{KONCEPTUALNI IZAZOVI - DEFINIRANJE LIJENOSTI}

Laički gledano, lijenost označava karakternu osobinu koja je naoko poprilično jasna, ali kada o njoj razmislimo, otkrivamo kompleksnost različitih elemenata koji čine lijenost. Uobičajeni načini za opisivanje lijene osobe su da se radi o osobi kojoj je teško ispuniti svoje obaveze, ili ih uopće ne želi ispuniti, da je to osoba koja ne pokušava dovoljno uspjeti u nečemu, kasni na dogovore, teško mijenja navike i tomu slično. Već i iznijeta skica laičkog razumijevanja lijenosti sadrži određena oprečna značenja; primjerice, je li lijenost voljni čin ili rezultat dublje odrednice osobnosti nad kojom nemamo kontrolu? Laik bi na to mogao odgovoriti da je netko „jednostavno takav“, dakle da se radi o inhe-

1 Prokrastinaciju zasad tentativno možemo definirati kao voljno odgađanje obaveza ili planova na vlastitu štetu. Podrobnije određenje pojma uslijedit će uskoro. 
rentnoj karakternoj osobini. U znanstvenoj literaturi nije lako pronaći pojam „lijenost“, već se puno lakše pronalazi srodni termin prokrastinacije.

\subsection{Pojam prokrastinacije}

Prokrastinacija je suvremeni termin za lijenost, u njegovom kliničkom i preciznijem značenju. Tim se pojmom opisuje određeno ponašanje i manje je apstraktan od pojma lijenosti, podložnom raznolikim interpretativnim manevrima, iako ni prokrastinacija, doduše, nije jednoznačan pojam. Ipak, možemo prepoznati neke dominantne elemente u definiranju prokrastinacije. Osnovna definicija bi bila da je prokrastinacija voljno odgađanje obaveza ili planova na vlastitu štetu pri čemu se misli na negativne emocije koje osobe koje svojevoljno odgađaju obaveze osjete. Solomon i Rothblum (1984, prema Senécal i sur., 1995:608) tako definiraju prokrastinaciju kao čin nepotrebnog odgađanja zadatka do točke kada iskusimo nelagodu.

Ferrari smatra da je prokrastinacija jedno od bazičnih, univerzalnih ljudskih ponašanja koje sve individue katkad iskuse (prema Smith i Saelinger, 2015:101). Svi do neke mjere odgađamo jer vršimo proračune između primarnih lako dohvatljivih želja i sekundarnih, teže dohvatljivih, a prokrastinacija se pojavljuje kada lakše možemo dobiti nagradu povezanu s nekom primarnom željom. Pychyl (2008) prokrastinaciju smatra samo dijelom šire grupe ponašanja koja se može podvesti pod zajednički nazivnik neuspjeh samoregula$c_{i j e^{2}}$. Neuspjeh samoregulacije se pojavljuje kao okidač prokrastinacije. Senécal i suradnici (1995) to opisuju na sljedeći način: znamo da imamo zadatak koji moramo obaviti, i čak ako želimo obaviti taj zadatak, ne možemo se motivirati da zadatak obavimo u željenom ili očekivanom vremenskom okviru. Tipično se odgađa početak izvršavanja zadatka sve dok ne osjetimo nelagodu. Prokrastinacija je dijelom motivacijska poteškoća, ali dodatni faktori poput loše organizacije vremena i krive predodžbe te uvjerenosti u vlastitu produktivnost dodatno je pospješuju. Ta kriva uvjerenja su obično „radit ću bolje pod pritiskom“ ili „osjećat ću se bolje ako kasnije ovo uradim“ (Szalavitz, 2003:50).

Ferrari i Demir (2009:302-303) razlikuju 3 oblika kronične prokrastinacije: prokrastinaciju utemeljenu na odlukama, uzbudenju i izbjegavanju. Odgađanje odluka karakterizira nemogućnost da se donese odluka u određenom periodu. O drugom je tipu riječ kada pojedinac namjerno čeka zadnji tren za izvršavanje određene obveze ne bi li iskusio uzbuđenje i satisfakciju zbog „pobjeđivanja sata“. Nadalje, prokrastinaciju utemeljenu na izbjegavanju sačinjava odgođena motivacija zbog straha od neuspjeha. Naposljetku, kronična prokrastinacija obilježena je izbjegavanjem inicijacije, izvedbe i kompletiranjem zadatka (Ferrari i Demir, 2009).

Na tragu maločas iznijete distinkcije, Schouwenburg i suradnici (2004, prema Owens i sur., 2008:366) razlikuju prokrastinaciju kao stanje (engl. state) i prokrastinaciju kao

$2 \mathrm{U}$ tu grupu spadaju još kompulzivna ponašanja, poput prejedanja ili gomilanja stvari, te diferentne ovisnosti.

$3 \mathrm{U}$ engleskom izvorniku: decisional, arousal $\mathrm{i}$ avoidance. 
osobinu (engl. trait). Dok se prokrastinacija kao stanje pojavljuje samo u određenim situacijama te je specifična za prirodu određenog zadatka, prokrastinacija kao osobina konstantna je tendencija da se u svim (ili barem većini) situacija odgodi nužno postizanje zadanog cilja.

Reasinger i Brownlow (1996) opisuju proces onemogućavanja samog sebe u kojem pojedinci stvaraju barijere i / ili unaprijed izmisle moguće razloge za neuspjeh, a sve u svrhu zaštite slike o sebi ili zbog postizanja kratkoročnih pogodnosti.

$\mathrm{Na}$ razvoj prokrastinacije velik utjecaj imaju emocije i psihička stanja (Senécali sur., 1995). Solomon i Rothblum (1984, prema Senécali sur., 1995:608) vide strah od neuspjeha kao jedan od glavnih faktora čimbenika prokrastinacije. ${ }^{4}$

Negativne emocije koje se iskuse kroz prokrastinaciju pojavljuju se još u djetinjstvu, što Linda Gilmore i Gillian Boulton-Lewis smatraju vremenom kada okruženje najviše djeluje na formiranje motivacije djece. Kada djeca nisu motivirana i ne uspijevaju u školi, niti pokušaji za poboljšanjem ne polaze im za rukom, slaba motiviranost postat će inherentna karakterna slabost odnosno lijenost (Gilmore i Boulton-Lewis, 2009:95). Carter i Carter (2014) upozoravaju da označavanjem nekoga kao lijenog može rezultirati internalizacijom takve oznake i preuzimanjem korespondentnog modela ponašanja. Berger i Luckman smatraju da su licem u lice interakcije najsnažniji mehanizmi internaliziranja znanja o sebi pa ako dijete od autoriteta čuje da je lijeno, to može lako internalizirati (prema Wallace i Wolf, 1999: u Kosmas, 2003:75).

Na prokrastinaciju se uglavnom gleda kao na negativnu pojavu, ali Chu i Choi (2005, prema Choi i Moran, 2009:196) smatraju da svi oblici prokrastinacije ne impliciraju nužno negativne ishode. Ovi autori, naime, razlikuju dvije vrste prokrastinatora: pasivne i aktivne. Dok se pasivni prokrastinatori ponašaju sukladno konvencionalnom viđenju prokrastinatora, aktivni prokrastinatori namjerno prokrastiniraju kako bi iskoristili snažnu motivaciju vremenskog pritiska za uspješno postizanje zadatka. Tako oni pokazuju percepciju vremena, stavove, nošenje sa stresom i akademski uspjeh sličan, katkad čak i bolji, od ne-prokrastinatora. ${ }^{5}$

Birkelund (2016) također ukazuje na mogućnost pozitivnih oblika prokrastinacije, što naziva racionalnom lijenošću. Racionalna je lijenost strategija troškova i koristi kad u ograničenom vremenu donosimo odluke temeljene na automatskim mentalnim procesima. Autorica navodi primjer poslodavca koji kandidate za razgovor za posao bira prema svojoj

\footnotetext{
4 Strah od neuspjeha manifestira se na razne načine: kao strah od nastupa, perfekcionizam ili nedostatak samopouzdanja (Senécal i sur., 1995). Szalavitz navodi kako se perfekcionizam kod prokrastinatora formira zbog uvjerenja da prokrastinator mora udovoljiti nekome drugome. Kao izvorišta prokrastinacije apsotrofiraju se također impulzivnost odnosno nedostatak kontrole, želja za adrenalinom, depresija, nejasna očekivanja, nejasne upute, nejasni prioriteti i utjecaj roditelja. Roditelji koji kažnjavaju svoju djecu mogu u njima izazvati karakteristiku da odgađaju donošenje odluka zbog straha od kritiziranja ili kazne. Roditelji koji djeci ne daju moć odlučivanja i rade puno toga umjesto njih također mogu razviti nemogućnost donošenja odluka (Szalavitz, 2003).

5 Uputno je navesti da Choi i Moran (2009) prokrastinaciju vide kao ponašanje vezano uz određene zadatke, dakle ne kao stanje tj. karakternu osobinu pojedinca.
} 
automatskoj klasifikaciji unutarnjih i vanjskih grupa, što konkretno znači da će prije birati „domorodce“ nego strance za razgovor. Pri tome, Birkelund napominje da se akcije aktera često razlikuju od njihovih stajališta, naročito ako se u vremenskoj stisci oslone na automatske procese poput ovog. U situaciji kada je vrijeme ograničeno, dijapazon mogućih izbora velik, a potrebno je donijeti jasnu odluku, ljudi će gravitirati kognitivnoj lijenosti. Ukratko, razvidno je da je teško ponuditi jednoznačnu definiciju lijenosti. S jedne strane zamjetno je vrlo široko kolokvijalno poimanje lijenosti koje može poprimiti niz značenjskih nijansi koje, unatoč sličnosti, izmiču preciznom određenju. S druge strane, zastupljeno je vrlo usko kliničko shvaćanje lijenosti koje kroz koncept prokrastinacije lijenost opisuje kao individualni čin odgode izvršenja određenog zadatka. Premda nije prijeporno da se lijenost očituje kroz pojedinačne akcije u čijoj podlozi stoje određeni psihološki atributi, naša je intencija transcendirati takvo, u osnovici psihologijsko stanovište te lijenost razotkriti kao koncept koji esencijalno ima sociokulturno izvorište. Lijenost se, štoviše, tek može pojaviti kao dio specifičnih sociokulturnih (i socioekonomskih) sklopova. No, prije nego li se poduhvatimo naznačene zadaće, potrebno je barem ugrubo distingvirati koncept lijenosti u odnosu spram dobrano vezanog koncepta dokolice, odnosno slobodnog vremena.

\subsection{Relacija dokolice i lijenosti}

Odjeljak donosi komprimirani pregled u sociološkoj literaturi podosta izdašnog tematiziranja dokolice. Postoje razne definicije dokolice, ali Haywood i suradnici (1995, prema Chua, 2001:31-32) supsumiraju ih pod nekoliko tema: dokolica kao rezidualno vrijeme, dokolica kao aktivnost, funkcionalna dokolica i dokolica kao sloboda. Drugim riječima, dokolicu razumiju kroz dimenzije rada, vremena, aktivnosti, funkcije i slobode. Pojmljena kao rezidualno vrijeme, dokolica nastupa nakon što su podmirene obaveze nužne za preživljavanje. Haywood i suradnici (1995, prema Chua, 2001:31) navode da je ovaj oblik dokolice naročito prisutan u industrijskim društvima u kojima dokolica nastupa tek nakon radnog vremena. Ova koncepcija često zanemaruje druge oblike rada i obaveza koje nisu inkorporirane u radno vrijeme, poput kućanskih poslova, odgoja djece i posjete rođacima. Wagner i sur. (1989), Stebbins (1982), Arai i Pedlar (1997) te Kelly (1997) dokolicu također poimaju kao kategoriju onkraj rada, kao dvije odvojene pojave koje se ne mogu odvijati simultano (prema Chua, 2001:25). U ovome smislu, ako se dokolicom bavimo u prihvatljivom vremenskom odsječku, društveno okruženje nijednu dokoličarsku aktivnost neće osuditi kao lijenu. No, budući da postoje razni oblici neplaćenog rada i obaveza, lijenost se može manifestirati u odnosu na takve aktivnosti, naročito jer bez prinude novčane nagrade i strukture radnog vremena takve aktivnosti možemo odgađati ili zanemariti.

Dokoličarske aktivnosti donose zabavu i užitak. Obično se na rad i dokolicu gledalo kao na dualitet: rad je instrumentalan i obvezatan, dok je dokolica slobodno odabrana i samoj sebi svrha. Dokolica je u ovim koncepcijama svojevrsna fizička kategorija, odnosno karakteriziraju je određene aktivnosti koje pojedinci poduzimaju (Haywood i sur., 1995, prema Chua, 2001:31). Ako ovaj vid dokolice usporedimo s prokrastinacijom, 
vidimo da negativne emocije koje pojedinac osjeti mogu „pokvariti“ zabavnu aktivnost kojom smo odlučili zamijeniti neku obavezu. Drugim riječima, potreban nam je osjećaj da smo se zaslužili zabaviti, a pojedinac koji prokrastinira neće imati taj osjećaj pa je užitak u bilo kojoj zabavnoj aktivnosti potencijalno umanjen. Ovaj pogled odgovara koncepcijama dokolice kao stanja uma. Russel i Stage tvrde da se dokolica mora razumjeti u odnosu na slobodu djelovanja, donošenju odluka i slobodu u vremenu i prostoru. Samdahl (1992, prema Chua, 2001:25) dokolicu vidi kao socijalno-psihološku percepciju aktivnosti u kontekstu svakodnevnog života. Dakle, dokolica se ne sagledava kao puko vrijeme u kojem se ne radi, već kao stanje uma u kojem se osjeća izvjesna sloboda. Samdahl naglašava da se takvo stanje obično odvija vikendom kada većina ljudi ne radi (prema Chua, 2001:25). Stari pogledi nastoje razdvojiti rad i dokolicu vrstom aktivnosti i fizičkim lokacijama, dok noviji nastoje razumjeti prirodu aktivnosti i zašto se neke razumiju kao rad a neke kao dokolica. Rad od kuće, poduzetništvo i drugi oblici rada pokazuju da su dokolica i radno vrijeme u današnjem svijetu fluidni. Lee i suradnici (1994, prema Chua, 2001:27) naglašavaju da su stanja svijesti tranzitorna, ljudi se podsvjesno prebacuju iz jednog u drugo, ne odlučuju svjesno koje će stanje uma imati. Psihološku razinu pojedinaca ne možemo potpuno zanemariti, ali na umu svakako valja imati način na koji društvo uokviruje individualna stanja svijesti.

Koncepcije dokolice kao funkcionalne kategorije razmatraju njezinu korisnost za pojedinca ili društvo. Ona je sredstvo za postizanje društveno prihvatljivih i poželjnih rezultata (Haywood i sur., 1995, prema Chua, 2001:32). Te su koncepcije širokog raspona, ne reduciraju dokolicu na određenu vrstu aktivnosti, ili u vrijeme van radnog vremena, već dokolicu vide kao sve što može ponuditi sredstava za realizaciju želja i za ostvarivanje društvenog prihvaćanja (Haywood i sur., 1995, prema Chua, 2001:32). Mannell i Goodale (1980, prema Chua, 2001:26) dokolicu shvaćaju kao pozitivno ponašanje koje pridonosi dobrobiti zajednice. Grayling (2000), Allen (1991) te Arai i Pedlar (1997) naglašavaju važnost dokolice za satisfakciju pojedinca (prema Chua, 2001:26). Auld i Case (1997, prema Chua, 2001:26) navode da je dokolica oblik socijalne interakcije. Kelly (1997, prema Chua, 2001:28) upozorava na negativne strane dokolice, poput alijenacije između članova obitelji koji ne dijele iste oblike dokolice. Ovdje je glavni prijepor kako društvo ocjenjuje određene oblike dokolice. Je li svaki oblik dokolice jednak? Ako je u tenziji s društvenim normama i vrijednostima, neki način provođenja vremena mogao bi se osuditi, a možda i ocijeniti lijenim.

Dokolica kao sloboda označava mogućnost pojedinca da se posveti čemu god zaželi. Ovdje je središnji koncept odabir, ali u kontekstu modernoga kapitalističkog društva, sloboda izbora ograničena je društvenim strukturama. Neke dokoličarske aktivnosti možemo raditi iz osjećaja obveze, ili zato što nam okolnosti ne pružaju druge oblike dokolice (Chua, 2001:28). Neomarksističke teorije naglašavaju dokolicu kao područje komercijalizacije i komodifikacije. Frankfurtska škola upozoravala je na rast kulturne industrije, koja putem masovnih medija i masovnih oblika zabave ${ }^{6}$ eksploatira pojedin-

6 Poput kina, televizije, sportskih aktivnosti, čitanja stripova itd. 
ce i homogenizira kulturu (Marshall, 2003). Hall i suradnici (1975, prema Marshall, 2003), s druge strane, vide dokolicu kao područje otpora naspram dominantne ideologije. Tako ponovno dolazimo do ideje da određene aktivnosti imaju veću društvenu prihvaćenost, pa se neprihvaćene aktivnosti mogu vrednovati kao gubitak vremena ili čak lijenost. Također, ove teorije daju nam prostora za pozitivnu ocjenu lijenosti. Izbjegavanjem društveno prihvatljivih aktivnosti i prepuštanju vlastitoj slobodi možemo razvijati individualnost i distancirati se od sustava konstantne potrošnje.

Ukratko, odnos između dokolice i lijenosti nipošto nije jednoznačan. Ovisno o interpretativnim okvirima te napose normativno-vrijednosnim stanovištima, sfera dokolice može se sagledavati kao područje u kojem nije prisutna lijenost $s$ obzirom da su se obaveze implementirale u sferi nužnog rada. Međutim, postoji tip radnih aktivnost neobuhvaćen kategorijom radnog vremena tako da se i unutar slobodnog vremena može govoriti o lijenosti ako određeni poslovi nisu obavljeni ili već ako zbog toga nije prisutan osjećaj slobode svojstven dokoličarenju. S druge strane, pojedini teorijski pristupi pozdravljaju lijenost kao svojevrsni subverzivni akt odmaka od dokolice kolonizirane potrošačkom logikom kapitalističkog sustava. Prema tome, relacija dokolice i lijenosti izuzetno je složena i zasigurno iziskuje podrobnija istraživanja, posebice u društvima 21. stoljeća gdje je granica između sfera rada i slobodnog vremena iznimno tanašna i nerazvidna.

\section{SOCIOKULTURNA „IZVORIŠTA“ LIJENOSTI}

\subsection{Lijenost i vrijeme}

U ovoj svojevrsnoj kratkoj sociokulturnoj retrospektivi društvenog poimanja lijenosti, potrebno je vratiti se sve do ranog razdoblja društvene organizacije odnosno do društava koje se u literaturi nerijetko (neopravdano) običavaju nazivati „primitivnima“. Druga preliminarna napomena važna za ovaj rakurs jest da je za pojam lijenosti apodiktična kategorija vremena, odnosno da se koncept lijenosti uopće može pojaviti u tijesnoj vezi spram diferentna poimanja vremena. Baudrillard (1998) je u svojoj usporedbi modernih i primitivnih društava naglasio upravo razlike u koncepciji vremena. Vrijeme je kategorija prezentna samo u određenim tipovima društva, odnosno u društvima sa specifičnim formama ekonomske produkcije. Moderno kapitalističko društvo vrijeme prepoznaje kao jedan u nizu objekata kojima se obavlja razmjena, dok „primitivna društva“ ne poznaju vrijeme. $U$ takvim se društvenim formacijama život (biološki i društveni) shvaća ciklično, kao kontinuirano ponavljanje važnih događaja kao što je žetva, praćenih kolektivnim događanjima, poput gozbi, plesova ili drugih rituala. U primitivnim je društvima život toliko vezan uz prirodne cikluse da se oni ne prepoznaju kao distinktivna vremenska kategorija. Doduše, izvjesna ideja ponavljajuće cikličnosti jest prisutna, ali nema ideje protoka vremena, napose ne u linearnom smislu. Stoga ovdje nije prisutan ni koncept slobodnog vremena. Andreou (2007) naglašava kako je u životinjskoj prirodi (također i ljudskoj) fokus usmjeren na sadašnje zadovoljstvo, a ne na proračun moguće buduće koristi. Pelusi (2007) također ističe da postoji prirodna inklinacija ka odabiru sadašnje ugode jer je budućnost 
ionako nesigurna. Impulzivnost, karakteristika koja može biti povezana s lijenošću, nekoć je bila potrebna za preživljavanje. Pripadnici primitivnih društava tendirali bi zadovoljiti svoje osnovne potrebe, izbjeći opasnosti i taj ciklus ponavljali bi do smrti. Odmor i rad su se prirodno izmjenjivali po potrebi. Rezultat rada se odmah mogao uživati i direktno je koristio pojedincu. Teorijski gledano, dakle, lijenost se u ranim društvima jednostavno nije konceptualizirala, jer su ljudi živjeli za podmirenje svojih potreba i izbjegavanje opasnosti. Još je i Aristotel upozorio na antropološki atribut da ljudi biraju ono što im pruža užitak, a izbjegavaju ono što je bolno (Aristotel, 1999) i u tom smislu djelovanja pripadnika primitivnih zajednica itekako su logična, oportuna i plauzibilna. Kada se onda pojavljuje ideja lijenosti?

Glantz (1989, prema Pelusi, 2007:64) smatra da se lijenost pojavila kada je postalo moguće planirati budućnost. Tekovina je to društvenog razvitka koja se pojavljuje u kompleksnijim društvima. Naime, razvoj sjedilačkog načina života omogućio je gomilanje proizvodnih viškova, a stabilniji izvori hrane i drugih resursa omogućili su porast stanovništva. Demografskim rastom usložnjava se društvena organizacija, diferenciraju se zaduženja, intenzivira se razvoj kulture i tehnologije. Vrijeme se počinje konceptualizirati: davna povijest objašnjava se mitovima i legendama, sadašnji protok vremena prati se izmjenom dana i noći, a budućnost se predvida promatranjem astronomskih tijela. Baudrillard izdvaja kronometriju kao jednu od krucijalnih razlika između primitivnih i modernih društava. Dok su primitivna društva tijek vremena mogla percipirati samo kroz promatranje prirodnih ciklusa, razvojem tehnologije u modernim društvima i izumom satnog vremena vrijeme postaje mjerljivo, te time objekt koji se može numerički izraziti i njime manipulirati (Baudrillard, 1998). Vremenom, koncepcija vremena se iz nesvjesne cikličke koncepcije transformira u svjesnu, mjerljivu i linearnu koncepciju. Svjesnost o vremenu te njegova kvantifikacija omogućuje definiranje vremenskih odsječaka s različitim funkcijama, što će rezultirati razlikovanjem slobodnog i radnog vremena. Tek s idejom linearnog protoka vremena može se pojaviti pojam lijenosti. Individuum, naime, događaje može rasporediti u sekvencijalni niz od prošlosti, preko sadašnjosti prema budućnosti. Nad prošlošću je moguća refleksija, u sadašnjosti se odvija konkretna akcija a budućnost uključuje planove ili projekcije trenutno teško ostvarivih želja. No, u pozadini su uvijek djelatni arhetipski, u osnovici životinjski, impulsi za realizacijom trenutačnog užitka. Andreou (2007:185) opisuje dvije razine želja: dok prvu razinu čine one koje možemo ostvariti u kratkom vremenu i rezultiraju poželjnom nagradom, na drugom nivou prisutne su još primamljivije želje koje impliciraju izdašniju nagradu, no njihova je vremenska cijena znatno viša. Kada se približi prilika za nekom nagradom, njezina vrijednost će nadmašiti vrijednost vremenski još udaljenije nagrade. Ljudi imaju tendenciju ponavljati stimulativne akcije, tj. one za koju smo dobili nagradu pa pojedinac tendira fokusirati se na trenutačne užitke (Kosmas, 2003). Jedan mogući pogled na lijenosti jest da se radi o ispunjavanju samo trenutnih poriva koji ne zahtijevaju puno truda, ali pitanje je da li bi to razumjeli kao lijenost bez vremenske koncepcije o prikladnosti takvog ponašanja. Drugim riječima, postoji vrijeme primjereno za takvo ponašanje, kao što je odmor za vikend, ali ako je takav način ponašanja konstantan i ponavlja 
se $\mathrm{u}$ neprimjerenim intervalima, primjerice na radnom mjestu ili za vrijeme nastave $\mathrm{u}$ školi, društveno okruženje individue sklone takvom ponašanju ocjenjuje kao lijene. Broj manjih, ali lako dosežnih nagrada zasigurno će nadmašiti one koje zahtijevaju dug vremenski ulog, pa kada osoba ponavlja biranje trenutačnog užitka povjerovat će da takvo ponašanje definira njezinu osobnost. Ipak, naše svakodnevne aktivnosti ne moraju nužno zrcaliti preferencije i želje niti otkrivati elemente podsvijesti koji nam onda govore što zapravo želimo ili što bismo zapravo trebali raditi (Andreou, 2007). ${ }^{7}$

Inauguraciji ideje lijenosti u društveno-organizacijskom smislu u okvirima zapadne civilizacije zasigurno je značajno pridonijelo kršćanstvo odnosno institucija Crkve, osobito društveno moćna u predmodernoj epohi. Organizacijsko ustrojstvo i radni režim tjedna u kojem dominantni dio vremena treba raditi, a tek je finalni odsječak tjedna, odnosno „ne-djelja"8, rezerviran za predah od mukotrpnog rada deriviran je iz biblijskog poimanja da je Bog stvorio svijet u sedam dana te se sedmog dana odmarao. Tako dolazimo do uvida da je ideja lijenosti dobrano uronjena u sustave religijskih vjerovanja.

\subsection{Religijski korijeni koncepta}

Motiv lijenosti nerijetko je zastupljen u setu vjerovanja različitih religijskih sustava te je u pravilu popraćen pejorativnim konotacijama. Lijenost se u osnovici poima kao antiteza vjernikovom pozivu, kao, u kršćanstvu primjerice, jednim od sedam smrtnih grijeha. LaMothe (2006:4) je analizirao kršćansku koncepciju lijenosti kao grijeha te naglašava kako se grijeh gleda kao voljni čin individuuma koji ljudsku volju distorzira s negativnim osjećajima anksioznosti, poniženja i straha. Konkretno, grijeh lijenosti LaMothe (2006:4) opisuje kao nedostatak spontanosti, vitalnosti, zaigranosti i znatiželje kod ljudi, generalno kao nedostatak volje. Grijeh je rezultat toga da nam je volja i stav toliko kolonizirana negativnim osjećajima da nam se alijenirajući i destruktivni činovi čine normalnima. Citirajući definicije starih redovnika, LaMothe (2006:5) pokazuje da je zajednički motiv u njihovom poimanju lijenosti ravnodušnost implicirana lijenošću koja potom vodi prema činjenju zlih djela. Toma Akvinski (1968, prema LaMothe, 2006:6) je kao uzrok lijenosti naveo depresiju, pri tome govoreći da lijenost nije nužno neproduktivnost, već izostanak volje za činjenje dobrog, iako djelatna osoba razaznaje kategoriju dobra. Novije definicije redovnika dodaju društveni element, gdje je lijenost zanemarivanje ne samo svojih dužnosti, već i dužnosti prema svojim susjedima, te izdvajaju i politički element prema kojem lijenost označava apatiju prema društvenom stanju i njihovoj mijeni. Redovnici bi lijenost obično simbolizirali u vidu raznih demona koji oduzimaju volju za djelovanjem. ${ }^{9}$

\footnotetext{
7 Sekundarne želje, ako ih imamo, su nam primamljivije od primarnih, ali upravo razmatranje vremena nas može spriječiti u njihovom ostvarivanju. S jedne strane to može biti kalkulacija da „imam dosta vremena za to, ne moram se žuriti“, a s druge strane može biti svojevrsni strah ili očajavanje: „koliko će mi samo vremena za ovo trebati, neću nikada to završiti."

8 U hrvatskome jeziku je pojmovna oznaka za sedmi dan u tjednu u tom smislu semantički vrlo efektna. 9 LaMothe (2006:7) ovaj proces dodatno ilustrira interesantnom paralelom s feminističkim teorijama patrijarhata: isto kao što grijeh lijenosti kolonizira misli pojedinca $s$ negativnim emocijama indiferentnosti i
} 
LaMothe (2006:7) naglašava kako se lijenost prije gledala kao stanje čitavog duha ili psihe pojedinca. Nasuprot takvoj univerzalističkoj poziciji za njega je uvjerljiviji partikularistički stav prema kojem se lijenost pojavljuje u određenim situacijama pod specifičnim uvjetima. Lijenost je ravnodušnost prema dobru i zlu, ono se poima kao gubitak volje i strasti za dobrotom. Lijenost je stanovita ravnodušnost, uz koju dobrota još ipak ima izvjesnu manju vrijednost, no ona reprezentira korak prije depresije, obilježenoj posvemašnjom ravnodušnošću kombiniranom s osjećajem bespomoćnosti i uzaludnosti (LaMothe, 2006:8).

Lijenost se negativno valorizira i u ostalim svjetskim religijama. $U$ jednom od budističkih svetih tekstova koji se nalazi u Pali kanonu govori se o smetnjama koje onemogućuju put prema prosvjetljenju, među kojima se ubraja i lijenost, ovdje opisana kao lijenost i tromost. Lijenost je naročito oprečna meditaciji koja od pojedinca iziskuje koncentraciju i trud (Thera, 1994).

U Yogattatva Upanishadi, jednim od hinduističkih svetih tekstova, lijenost u praktičnom pogledu predstavlja prepreku za izvođenje yoge, što mudar čovjek snagom svojih vrlina mora nadvladati. Također, potrebno je spomenuti koncept karme prema kojem je za očekivati da će lijenost biti kažnjena odgovarajućim karmičkim odgovorom (Ayyangar, 1938:351)

U islamu, lijenost nije supsumirana pod set glavnih grijeha (Al-Kaba’r), ali se spominje unutar haditha, tekstova koji prijenose riječi, djela i navike proroka Muhameda. Tamo se Allah priziva za spas od lijenosti (Sahihal-Bukhari, 6369).

Židovska religija broji 613 zapovijedi, ali one ne ekspliciraju pojam lijenosti. Lijenost se spominje u Pirkei Avot (hrv. Etika naših očeva) koja zagovara inicijativu i nuždu za završavanjem zadataka (Pirkei Avot, 2:15).

Iako su navedene religije nastale u raznovrsnim kulturnim i povijesnim kontekstima, zajednička im je poveznica, dakle, dominantno negativno shvaćanje lijenosti. Tradicionalno gledano, napose u predmodernim društvima, religija dobrim dijelom definira vrijednosti i norme koje se potom ugrađuju u individualne habituse i konkretne prakse. Religijske maksime reprezentiraju snažne regulatore ponašanja kroz koje se promiče radišnost a osuđuje lijenost.

\subsection{Protestantska etika i duh lijenosti}

Osebujno je protestantsko poimanje lijenosti koje se zrcali ponajprije kroz Weberovo poznato tematiziranje relacije između etičkih vrednota protestantizma i uspona kapitalističke privrede. Marx (1973, prema Rota, 2012:129) je smatrao da generiranje viška zahtijeva populacijski višak i mogućnost da se osobna dobrobit odgodi kako bi se višak uložio u razvoj proizvodnih sredstava. Weber je (1958, prema Rota, 2012:129) kritizirao Marxov nedostatak objašnjenja od kuda taj impuls odgode dolazi, te je to

depresije te tako sprečava njegovo djelovanje, tako i patrijarhat svoje idejne strukture inkorporira u kognitivni sklop žena i čini ih apatičnima prema možebitnom iniciranju promjena. 
objasnio tezom o protestantskoj etici i duhu kapitalizma. Reformatorski pokret i iz nje iznjedrena protestantska etika stvorila je nekoliko elemenata ključnih za nastanak kapitalizma. Prvi je osjećaj krivnje zbog slobodnog vremena odnosno s istim skopčanom lijenosti. Lijenost reprezentira moralno propadanje nasuprot radu i produktivnosti koji označavaju pobožnost. Uživanje u slobodnom vremenu legitimno je tek u transcendenciji, dakle nakon smrti u raju, ali ta se ugoda prethodno mora zaslužiti radišnošću u ovozemaljskom životu (McCormack, 1971:160). Drugi važan element jest osjećaj dužnosti. Svaki pojedinac ima poziv: odgovorno obavljanje svojih dužnosti kao krajnji ideal prema kojemu treba težiti jer je tek na taj način moguće približiti se Bogu. Iz takve pozicije proizlazi da spas vjernika više nije u domeni svećenika, već u njegovoj vlastitoj i koji kroz obavljanje dužnosti može zavrijediti spas. Sveti poziv za radišnost transmutira u sekularni osjećaj dužnosti prema poslu. Vjerovanje u predestinaciju važna je komponenta protestantske etike baštinjena kroz kalvinističko učenje. Međutim, predestinacija može stvoriti plodno tlo za lijenost. Naime, ako je nekome sudbina predodređena, izlišnom postaje potreba za ulaganjem bilo kakvog napora. Protestantska etika osuđuje takvu apatiju i kroz ideju poziva stvara motivaciju za radom i općenitim bivanjem, jer poziv nije po automatizmu poznat pojedincu, već se mora iskristalizirati kroz rad. Protestantska etika također nalaže izbjegavanje iskušenja za stjecanje osobne sreće, odnosno potrebu za izbjegavanjem sebične motivacije, što znači da profit koji radom steknemo valja štedjeti. Marljivim radom i štednjom se polako akumulira novčano bogatstvo što se manifestira kao predestinirana božja nagrada za uloženi trud (Hewa, 1998:141; za čitav odjeljak konzultirati posebice Weber, 2006).

\subsection{Lijenost u modernim kapitalističkim društvima}

Prethodno smo akcentirali da je koncept lijenosti tijesno povezan s inauguracijom linearne koncepcije i kvantifikacije vremena. Sve preciznije mjerenje vremena omogućuje precizniju kontrolu nad vremenom, čime se istovremeno omogućuje veća kontrola nad pojedincima u društvu. Kontroliranje vremena steklo je svoj prvi vrhunac u industrijskoj revoluciji, kada, kako navodi Pelusi (2007:65), nastaju rigorozni vremenski rasporedi. Striktni rasporedi, koje definira satno vrijeme, nastaju uglavnom zbog potrebe da se stvori radna etika koja će podržati kapitalistički sustav proizvodnje. Thompson (1967, prema Rota, 2012:130) navodi najvažnije elemente u edukaciji radnika za kapitalistički način rada: nadzor, kazne, zvono i satovi, novčani poticaj, propovijedi i škole te supresija sajmova i sporta.

$\mathrm{Na}$ radnome mjestu, pojedinci na poziciji autoriteta nadgledaju rad radnika osiguravajući da se odvija po odgovarajućoj proceduri dizajniranoj za maksimiziranje efikasnosti rada. Također, nadzornici održavaju disciplinu među radnicima, smanjujući „nepotrebno" socijaliziranje ili bilo koje druge izvore smetnji za radni proces. Kazne služe kao krajnje mjere za održavanje discipline i oblikovanje preferiranog tipa ponašanja. Propovijedi i škole također ugrađuju željene norme, vrijednosti i ponašanje u pojedince, a supresijom sajmova i sporta smanjuju se prilike za ekscesivno slobodno ponašanje 
(Rota, 2012:131). U liberalnome (kapitalističkom) sustavu razvija se specifičan koktel organiziranih praksi, tehnika, diskurzivnih elemenata i mentaliteta koji konstituiraju logiku upravljanja (fra. gouvernementalité) a čija je temeljna funkcija upravljanje odnosno svojevrsna kontrola stanovništva (Foucault, 2016). Logika upravljanja utisnuta je u kognitivne strukture pojedinaca što reprezentira određenu funkciju samokontrole, vladanja sobom (i drugima) (Foucault, 1988, prema Paić, 2013:200), a čime individue i same doprinose reprodukciji cjelokupnog poretka. Unutar takvog horizonta lijenost se izgledno može doživljavati tek u negativnim terminima.

Radni dan u liberalno-kapitalističkoj socioekonomskoj formaciji točno je određen satnim vremenom, a zvona služe za signaliziranje važnih točki u vremenu (poput pauzi ili završetka radnog dana). No, satno vrijeme ne definira samo trajanje radnog dana, ono je sveprisutan element u kapitalističkoj proizvodnji. „Vrijeme je novac“ jedna je od temeljnih maksima kapitalizma (Rota, 2012:130). Efikasnost radnika mjeri se vremenom, a proizvodni procesi se taylorovskim metodama znanstvenog upravljanja svode na vremenski mjerljive korake. Poole (2013:24) je produktivnost (drugim riječima efikasnost) osudio kao metodu dehumanizacije ${ }^{10}$ radnika, gdje se radnik svodi samo na svoj proizvodni učinak.

Lafargue i Russell (Poole, 2013:25) kritiziraju zahtjev kapitalističkog sustava za što većim radom. Oni izvrću lijenost iz pozicije osuđene osobne karakteristike u ljudsko pravo i zahtijevaju bolju ravnotežu između rada i slobodnog vremena. ${ }^{11}$

Onkraj radnog vremena satno vrijeme ograničava raspon slobodnog vremena odnosno dokolice. Efikasnost je usko povezana s maksimiziranjem profita i konstantnim rastom karakterističnim za kapitalizam. Baudrillard (1998) navodi mitsku vrijednost vremena u tome što je to kategorija kojom se izjednačavaju sva ljudska stanja. „Svi su ljudi jednaki pred vremenom i smrti“ izreka je koja utjelovljuje moć vremena nad ljudima, a u kapitalističkom društvu ta se moć nastoji iskoristiti za upravljanje ljudima. Pollard (1965, prema Rota, 2012:131) navodi kako se ljude koji su naviknuti da rade samo za preživljavanje, a ne za maksimiziranje profita, moralo učiniti poslušnima prema novčanom stimulusu. Bez te edukacije, radnici nemaju želju gomilati svoje prihode, već samo rade koliko moraju i nakon toga preostalo vrijeme i zarađeni novac konzumiraju u dokolici. $\mathrm{Za}$ rast industrijalizacije, nije dovoljno bilo ponuditi samo novčanu nagradu radnicima, potrebna je bila promjena njihovog vrijednosnog etosa kako bi rad usmjeravali u svrhu stjecanja profita odnosno štednje (prema Rota, 2012:131). To se djelomično postiže stavljanjem naglaska na radišnost per se kao aksijalnu vrijednost. De Vries (1994, pre-

10 Takvu dehumanizaciju moguće je objasniti kao nuspojavu znanstvenog upravljanja radom - kako bi se neka aktivnost mogla analizirati i za nju pronaći najbrži način izvedbe potrebno ju je apstraktno prikazati brojevima, pa je znanstvenom upravljanju najviše relevantan proizvodni učinak koji se mjeri dobivenom količinom proizvoda u određenom vremenu.

11 Zanimljivo je što rješenje vide u kvalitetnijoj mehanizaciji i automatizaciji proizvodnog procesa, čime bi se smanjila potreba za velikim brojem radnih sati, a što bi radnici pak mogli vidjeti kao prijetnju za svoja radna mjesta (Aronson, 2016). 
ma Rota, 2012:131) to opisuje kao supstituciju hedonističkog ${ }^{12}$ pristupa anti-hedonističkim. Rad tako postaje dominantna kategorija kojom se određuje vlastita vrijednost (Rota, 2012). Rezultat je radišnosti kupovna moć pa pojedinci troše zarađeni novac kako bi demonstrirali svoju vrijednost i zadobili respekt.

Moralni sustav kapitalizma cijeni radišnost, a osuđuje nekontrolirani hedonizam i slobodu prisutnu na sajmovima i sportskim događanjima svojstvenim za ruralna područja koja su se nastojala industrijalizirati (Rota, 2012). Kada se za društveni cilj postavi radišnost odnosno stjecanje profita, lijenost postaje riječ koja označava negativnu karakteristiku koju valja izbjeći, pa se zahtjev za više slobodnog vremena u startu može osuditi pozivanjem na negativnost lijenosti. Aronson (2016) smatra da je industrijalizacija katalizator ideje da je lijenost grijeh. Lijenost se iz osobne slabosti pretvorila u javnu prijetnju za funkcioniranje društva. Za kapitalističko društvo fundirano na konstantnom rastu i proizvodnji, lijenost predstavlja fundamentalnu suprotnost temeljnoj vrijednosti radišnosti.

Isti autor (Aronson, 2016) upozorava da konstantni imperativ produktivnosti ne ostavlja vremena za kontemplaciju u slobodnom vremenu što se negativno odražava na kreativnost i stvaranje novih ideja. I dok je za Aristotela (1999) kontemplacija koja se može implementirati tek u periodima izuzetosti od domene nužnog rada vrhovna ljudska aktivnost, u kapitalističkoj privredi orijentiranoj ka konstantnom rastu refleksivna djelatnost reprezentira dangubljenje.

Gorz, pišući o kraju radnog društva, govori o utopiji u kojoj se zbog procesa automatizacije sve više smanjuje centralna uloga rada u društvu. Pod radom on podrazumijeva rad svojstven industrijskom kapitalizmu. Za primjer daje odgoj djece: za ženu koja se brine za djecu kod kuće ne smatra se da je zaposlena premda vrši određenu vrstu rada, dok bi ista ta žena da se brine za djecu u određenoj odgojnoj instituciji bila u statusu zaposlene osobe. Rad se socijalno konstruira tako da mora biti uklopljen u društvenu razmjenu, a institucije kontroliraju procedure rada i stvaraju profesionalne standarde (Gorz, 1997, prema Kalanj, 1999:228).

Za razliku od ranijeg stadija kapitalizma obilježenog fordizmom i masovnom zaposlenošću, kasniji kapitalizam se razvio u postfordistički oblik kojeg karakterizira sve manji broj stalno zaposlenih. Recentni period obilježen je pojavom širokog spektra novih, nerijetko nazivanih, nestandardnih odnosno atipičnih oblika rada: privremeni rad, povremeni rad, samozapošljavanje, rad od kuće, rad s fleksibilnim radnim vremenom (Matković, 2004:245) prekarni rad (Standing, 2011) te srodni koncepti. Premda se na prvi pogled može učiniti da "klasična“ kapitalistička koncepcija rada erodira, ona u stvari transmutira i u svojim revidiranim inačicama možda još i obuhvatnije zahvaća životnu svakodnevicu ljudi u suvremenom društvu. Postfordističko društvo tako stvara temelje za još veću dominaciju kapitala nad životima pojedinaca. Sve je veća dominacija zakona tržišta

12 Za podrobnije pojašnjenje koncepta hedonizma (posebice u kontekstu kontrapozicije istog s konceptom eudaimonije) uputno je konzultirati Scollon i King (2004). 
koji ostavljaju najveći dio profita minimalnom broju najuspješnijih. Logika tržišta komodificira ne samo proizvode i usluge, već na određen način i same pojedince u potrazi za zaposlenjem. Nedostatak i nestalnost radnih mjesta zahtijevaju od pojedinaca da se natječu na tržištu rada te same sebe predstavljaju ${ }^{13}$ poput „proizvoda“: navode svoje poželjne karakteristike koje dokazuju navođenjem prijašnjeg radnog iskustva ili legitimitet potkrepljuju certifikatima o završenim školama, tečajevima i drugim oblicima obrazovanja. U takvom okruženju, rad zapravo postaje još zastupljeniji dio društvenog života, nauštrb dokolice, jer je prisutna konstantna briga oko pronalaska zaposlenja (Kalanj, 1999).

Pitanje je postaju li novije nestandardne forme rada, zapravo, novi standard i ne pojavljuje li se potreba za radikalnim redefiniranjem te kategorije. Stvari se dodatno kompliciraju ako $\mathrm{k}$ tome dodamo strukturnu nezaposlenost i općenito sve izraženije potiskivanje zamjetnog kontingenta stanovništva izvan sfere rada. Signali su to potrebe za iznalaženjem novih, adekvatnih modela ${ }^{14}$ reguliranja ekonomske osnovice društva te uopće načina utilizacije kreativnih impulsa građana. Za pretpostaviti je da bi se jedna takva korjenita rekonfiguracija odnos rada i kapitala te općenito izmijenjeno poimanje kategorije rada itekako reflektiralo na razumijevanje lijenosti iako se ovdje zbog limitiranosti prostora ne možemo upuštati u razradu hipotetskih scenarija te vrste.

\subsection{1. Životni stil, zdravlje i mediji}

Životni stil predstavlja moderni oblik distingviranja i diferenciranja među ljudima. Društveni se status ne derivira samo iz profesije ili radnog mjesta i privilegija, već načina na koji se privilegije i resursi koriste. Mnogi će zaposlenje odabrati upravo na temelju toga kakav će im biti životni stil, ali upravo slobodno vrijeme može biti jedno od glavnih područja u kojem se on definira i pokazuje (Baudrillard, 1998:156). Baudrillard smatra da je modalitet konzumiranja slobodnog vremena relevantniji od ukupne sume istog. Kvaliteta slobodnog vremena, njezin ritam i sadržaj, stvaraju razlike između klasa i grupa, ali i individua. U kontekstu konzumerističkog društva, vrijeme postaje još jedan komoditet. Rad je u svojoj osnovici davanje vremena za dobivanje nekog dobra (u konzumerističkom društvu je to najčešće novac) koje će pomoći u osiguravanju egzistencije. Pri tom se slobodno vrijeme sagledava kao rezidualna kategorija radnog vremena - to je jednostavno preostalo vrijeme koje na dispoziciji kada se ne mora raditi, a namijenjeno je za odmor da bi se moglo nanovo raditi (Baudrillard, 1998:152). Prema tome, dokolica nema svrhu u sebi samoj već ponajprije služi rekuperaciji za novi ciklus obavljanja radnih zadataka.

13 Takve su prakse samoreprezentacije efektno deskribirane u Bröckling (2016).

14 Kao što je, primjerice, prijedlog uvođenja minimalnoga zajamčenog dohotka (engl. guaranteed basic income odnosno universal basic income) za sve građane. Za iscrpno određenje predloženog modela te niz dalekosežnih društvenih reperkusija koje bi njegovo uvođenje impliciralo uputno je konzultirati zanimljive recentne debate sadržane u Haagh (2019), Lowrey (2018), Bregman (2016), Wehner (2019), također i Cunliffe i Erreygers (2004) za historijsku retrospektivu razvoja ideje. 
Vrijeme, pa tako i slobodno vrijeme, kao komoditet ima svoju uporabnu i razmjensku vrijednost. ${ }^{15}$ Bit slobodnog vremena jest vraćanje uporabne vrijednosti vremena, odnosno sloboda da se koristimo vremenom kako god poželjeli. U aktualnom konzumerističkom društvu, vrijeme se jedino može osloboditi kao objekt, odnosno mora se kronometrijski odrediti koliko nam vremena pripada, što nije uistinu sloboda vremena jer nam mjerne jedinice vremena nalažu „koliko smijemo biti slobodni“ (Baudrillard, 1998:153). Želja za slobodnim vremenom je kontradiktorna i očajnička, drži Baudrillard (1998:153), jer silna želja za slobodom pokazuje moć ograničenja koja društvo impostira, a nigdje ta kontrola nije potpuna i precizna kao u upravljanju vremenom kroz kronometriju.

Alijenacija slobodnog vremena nije samo očita $u$ tome što se $\mathrm{u}$ slobodnom vremenu odmaramo za radno vrijeme, već i okolnost da je zapravo nemoguće tratiti vrijeme. Čak i ljetovanje (ili sličan odmor) kojem je bit slobodno isključivanje iz vremenskih kalkulacija, koje obično uključuju pitanje jesmo li slobodno vrijeme zaslužili. Sve vrijeme zaslužujemo, jer i odmor je plaćen i omogućen cjelogodišnjim radom. To je konstantni sustav razmjene vremena: radimo kako bi dobili slobodno vrijeme, onda se odmaramo da možemo dalje raditi. Tome možemo i dodati razmjenu drugih komoditeta: radimo kako bismo stekli novac koji ćemo potrošiti u dokolici. Ranije faze kapitalizma se nisu toliko bavile dokolicom radnika, bilo je samo potrebno zadovoljiti minimalne potrebe kako bi se održala radna sposobnost. Sve raširenijom komodifikacijom, dokolica postaje prostor u kojem se od radnika očekuje da se ponaša kao potrošač, pa slobodno vrijeme postaje dio političke ekonomije (Debord, 2014:17). Slobodno vrijeme ne karakteriziraju kreativne aktivnosti, jer kreiranje, bilo umjetničko ili druge vrste, nije dokoličarska aktivnost. Dokolicu karakteriziraju „regresivne aktivnosti“ u smislu da postoje prije modernih oblika rada i moderne podjele rada (lončarstvo, ručni radovi, sakupljanje, ribolov). Model slobodnog vremena je djetinjstvo: sloboda i spontanost igre (Baudrillard, 1998:156). Rad i slobodno vrijeme definira ista dualnost: ograničenje i sloboda. Sloboda se manifestira uglavnom kao eskapizam i neodgovornost, jer pojedinac priželjkuje povratak spontanosti i totalitetu slobode slobodnog vremena, ali se ograničuje jer totalitet slobodnog vremena je neostvariv u društvu moderne podjele rada. Slobodno vrijeme je ideologija otuđenog rada. ${ }^{16}$

$15 \mathrm{Na}$ ovome je mjestu svakako potrebno akcentirati da je u ovome kontekstu shvaćanje uporabne vrijednosti vremena drugačije od Marxovoga izvornog shvaćanja. Marx, naime, u „Kritici političke ekonomije“ navodi da uporabnu vrijednost imaju komoditeti koji su opipljivi, odnosno fizički postoje (Marx, 1859). U „Kapitalu“ se također navodi da je uporabna vrijednost korisnost koja je vezana uz fizički predmet, a realizira se u trenutku uporabe ili konzumacije (Marx, 1867). Vrijeme je ovdje problematično jer je neopipljiva dimenzija prirode. Za Baudrillarda, vrijeme je a priori, transcendentalna dimenzija, ali postaje komodificirani objekt postupkom kronometrije, a uporabnu vrijednost određuje kvaliteta provedenog odnosno uloženog vremena (Baudrillard, 1998:152).

16 I u radu i u odmaranju traži se moralna i idealistična potraga za uspjehom. Nad ponašanjem djeluje ista radna etika koja stavlja naglasak na kvalitetu našeg „performansa“. Isto kako želimo uspjeti u radu, i to u suglasnosti s odobrenim parametrima (npr. novčano bogatstvo kao znak uspjeha), tako i u slobodnom 
Idealni odmor ukazuje na mehanike konzumerističkog društva koje su prisutne u svim aspektima ljudskog ponašanja: prva je maksimiziranje potreba i njihovog zadovoljavanja, ${ }^{17}$ a druga je kod distinkcije ili struktura diferencijacije - privilegirana elita je u prošlosti svoju moć demonstrirala besposličarenjem, danas to čini konzumacijom što više „beskorisnog“" vremena. To je ograničenje slobodnog vremena koje nalaže da se ne mora činiti ništa (korisno). Slobodno vrijeme je nejednako distribuirano. Potrošnja je toliko ugrađena u društvo da se sloboda od konzumiranja očituje kao razlikovno obilježje. Vrhunski menadžeri, koji rade po 15 sati dnevno, uživaju prestižni status. Rad se konzumira, rješava neurotičnu potrebu za bivanjem korisnim, preferira se nad slobodnim vremenom, a višak rada postaje znak prestiža i blagostanja. Vrijednost slobodnog vremena je u tome što je to vrijeme provedeno za proizvodnju vrijednosti svojeg statusa. Vrijeme u slobodnom vremenu nije slobodno, ono je potrošeno, dopuštamo si ga radom, ali nije potpuni gubitak, jer njegovim konzumiranjem dobivamo status koji pokazujemo životnim stilom. Slobodno vrijeme nudi priliku za manifestaciju vremenskog kapitala kojim raspolažemo (Baudrillard, 1998:158).

Foucault drži da je efikasnost državne moći bazirana na istovremenoj generalizaciji i individualizaciji. Slično funkcionira i domena zdravlja. Zdravlje je u svojoj osnovi individualno pitanje, ali u isto je vrijeme zdravlje pojedinaca od velike važnosti i za funkcioniranje društva. U modernom društvu postoji sustav zdravstvenog panoptikuma pred sve se postavlja obligatoran zahtjev usmjeren na održavanje zdravlja. Razlozi za održavanje dobrog zdravlja su individualna sreća, dug život, produktivna karijera, briga za djecu i tomu slično, ali istovremeno je javno zdravlje instrument društvene kontrole. Individue moraju biti zdrave kako bi mogle raditi i reproducirati se te tako održavali društvo. Loše zdravstveno stanje pojedinaca, osim što potencijalno umanjuje njihov potencijal za produktivnošću, predstavlja izdatak za državu koja pruža javnozdravstvene usluge (Kevin, 2007, prema Pakholok, 2013:3).

Ideja zdravog života rastuća je marketinška industrija. Paket usluge za teretane, organska hrana, dijetni planovi, sve su to proizvodi industrije zdravog života. Čak se i proizvode koji se ne smatraju zdravima, poput Coca-Cole, marketingom nastoji reprezentirati takvima. Zdrav je život ideologija i set generalne logike za prakse koje u praktičnom smislu nastoje utjeloviti tu ideologiju, ali s njom ne moraju nužno biti konkordantne. Zdravi životni stil obećava statusne nagrade za pojedinca - zdrav pojedinac postaje model discipline, odgovornosti i snage volje (Pakholok, 2013:4).

Ideologija zdravog života utječe na koncepcije slobodnog vremena. Pojedincu se nalaže iskorištavanje slobodnog vremena na razborit način, da radi na sebi i svojem zdravlju,

\footnotetext{
vremenu postoje konvencije odmora kojima se nastojimo prilagoditi. Sunčanje i dobivanje boje, razgledavanje što više znamenitosti, kušanje lokalne hrane, sve su to aktivnosti koje nam društvo predstavlja kao „dobar odmor" kojima se više ili manje konformiramo. Riesman (1964, prema Baudrillard, 1998) to naziva „fun-morality“ iliti ispravan način provođenja slobodnog vremena, odnosno zabavljanja.

17 To može biti maksimiziranje profita i proizvodnje, ali isto tako i što više sunčanja i razgledavanja znamenitosti na odmoru.
} 
da se bavi fizičkim aktivnostima i kloni štetnih aktivnosti. Iako je načelno pohvalna orijentacija prema održavanju zdravlja građana, u osnovici je riječ o još jednom načinu na koji se slobodno vrijeme u stvari čini manje slobodnim (Pakholok, 2013:3).

$\mathrm{Na}$ dnevnoj razini, pojedinci se moraju truditi i investirati kako bi konstanto reproducirali takav životni stil, ali tome prijete dvije bazične neurotične opsesije čovječanstva: lijenost i strah (Pakholok, 2013:7). Također, svaka vrsta svjesnosti povećava patnju: zdrav život nije uvijek ugodan, nego ponajprije reprezentira stalnu borbu. Lakše je prepustiti se užicima nego paziti na zdravlje (Pakholok, 2013). Zašto zdrav život kao životni stil nije disperziraniji? Za to su odgovorni duboki korijeni u kulturnom kodu zapadne civilizacije. Prema Eliasu (2000, prema Pakholok, 2013:8) civilizacija nastoji kontrolirati afektivnu stranu ljudi i umanjiti njezin značaj, ali naša tijela stalno diktiraju svoja pravila kroz stvaranje diferentnih ovisnosti (emocionalnih i fizičkih). Postoji nesuglasje između civilizacijom naučenih metoda kontrole tijela i moći pravila tijela, jer tijelo inklinira pružanju trenutačnih užitaka bez obzira na kasnije konsekvence (Pakholok, 2013:8).

Mediji značajno utječu na slobodno vrijeme. Konzumiranje medija može se najintenzivnije izvoditi u slobodnom vremenu. Mediji nude beskrajne sate zabave za konzumaciju, ali osim toga projiciraju razne oblike identiteta i sugeriraju mehanizme njegova stjecanja. Od načina zdravog življenja do izbora glazbe koje mediji prenose mogu utjecati na izbor kako provesti slobodno vrijeme pa je to još jedan izvor moguće neslobode slobodnog vremena, naročito ako se nekritički konzumira sve što mediji ponude. Razni akteri nalažu kako je najbolje provesti slobodno vrijeme, bilo da je riječ o reklamnom sadržaju koji promovira viši stupanj skrbi za vlastito zdravlje, ili drevni Aristotelov tekst koji kazuje da iako se trebamo baviti onime što iskazuje našu najveću vrlinu, filozofiranje ipak rangira kao superiorno svim ostalim aktivnostima (Aristotel, 1999:111).

I iz kraćeg pregleda načina na koji se problematika lijenosti tematizira u literaturi, razvidno je o koliko se slojevitom, višedimenzionalnom konceptu radi, tijesno isprepletenim $s$ razumijevanjem niza relevantnih atributa suvremenih kapitalističkih društva. Iako dosadašnja konceptualna rasprava nije uspjela iznjedriti određenu ni tentativnu definiciju koncepta lijenosti, smatramo vrijednim prilogom ukazivanje na širinu opsega tog pojma odnosno obuhvatan dijapazon njegovih potencijalnih empirijskih referenci. U nastavku ćemo se s teorijske ravni preseliti na empirijski nivo kroz prikaz ključnih nalaza istraživanja kojima je cilj bio proniknuti u način na koji lijenost razumiju i kakve ekspresije lijenosti eventualno pokazuju pripadnici/e studentske populacije, preciznije jednoga njezinog manjeg segmenta, u Hrvatskoj.

\section{EMPIRIJSKO ISTRAŽIVANJE}

S obzirom na neistraženost specifičnoga tematskog sklopa, prilikom dizajniranja istraživačkog nacrta, odlučili smo slijediti logiku izviđajnog, odnosno eksplorativnog istraživanja, fundiranog na kvalitativnom metodološkom pristupu. Za potrebe rada proveden je niz polustrukturiranih intervjua nad prigodnim uzorkom studentske populacije Fi- 
lozofskog fakulteta u Zagrebu. Istraživanje je odobrilo Povjerenstvo Odsjeka za sociologiju za prosudbu etičnosti istraživanja Filozofskog fakulteta Sveučilišta u Zagrebu 23.10.2017. koje, dakle, u dizajnu istraživanja i konkretnim protokolima nije identificiralo etički prijeporne elemente. Istraživanje je provedeno u razdoblju od listopada 2017. do veljače 2018. Poziv za istraživanje bio je javno objavljen, a odazvalo se 15 studenata/ ica s raznovrsnim kombinacijama studijskih grupa is različitih godina preddiplomskog i diplomskog studija. Intervjui su, uz privolu sugovornika/ca dakako, bili snimani (misli se na izradu zvučnog zapisa), a potom i transkribirani. Analitički postupci za vrijeme implementacije terena te posebice nakon što su svi intervjui realizirani, bazirali su se na kodiranju prikupljene empirijske građe s ciljem detektiranja stanovitih pravilnosti i obrazaca u zaprimljenim odgovorima. Takav induktivni analitički pristup (vidjeti Bendassolli, 2013; Hammersley, 1995) u osnovici reprezentira postupak apstrahiranja kroz koji se kroz intervjue disperzirani podaci sažimaju u sve rafiniranije konceptualne kategorije. Između mnoštva diferentnih strategija analitičkih strategija (Saldaña, 2009) odlučili smo se za tematsku analizu budući da smo apriorno definirali tematske motive u središtu našega istraživačkog interesa. Tu smo logiku konzekventno slijedili u svim sekvencama istraživanja: od planiranja preliminarnog protokola intervjua do analize građe te ćemo taj princip zadržati i prilikom predstavljanja najrelevantnijih nalaza istraživanja. Intervjue smo započinjali definiranjem lijenosti. Većina je sugovornika/ $\mathrm{ca}^{18}$ lijenost opisala kao nedostatak volje ili su naveli osobine (primjerice, neorganiziranost i neurednost) koje u suštini iz nje proizlaze:

„Lijenost za mene predstavlja snagu volje, ili možda bolje reći njezin manjak, za obavljanje fizičkih i mentalnih aktivnosti. " (student povijesti i njemačkog)

„Za mene lijenost predstavlja neizvršenje obaveza i ne samo neizvršenje nego nepravouremeno izvršenje obaveza. "(studentica njemačkog i sociologije)

Drugi/e sugovornici/e u pokušaju definiranja lijenosti iznijeli/e su ponešto konkretnije primjere:

„Kampanjstvo. U stilu učenja zadataka vezanih za faks ili za nešto šta naredi netko viši od nas, na višem položaju i jednostavno znači da radiš u zadnji čas za to." (studentica njemačkog i sociologije)

„Prva asocijacija mi je kao netko tko se ne može ustat' iz kreveta, ono da mu je baš teško. Ili osoba koja je lijena i neorganizirana." (studentica sociologije)

Većina sugovornika/ca smatrala je da lijenost posljedica dugoročnih „navika“. Drugim riječima, ukoliko se kod određene osobe inicijalno pojavi izvjesno lijeno ponašanje te se ono periodički ponavlja, lijenost postane svojevrsni vid navike koja se potom kontinuirano reproducira.

18 Sukladno važećim etičkim uzusima, sugovornicima/ama smo zajamčili anonimnost pa se izvadci iz empirijske građe donose pod relativno neutralnim deskriptorima („student/ica određene studijske grupe“) čime se onemogućuje prepoznavanje konkretnih sudionika/ca, ali se vrlo općenito naznačuje njihov „studentski profil“, barem kad je materija studiranja posrijedi. 
„Kad jednom kreneš bit’ takav, po meni, onda si takav uvijek. Znači nema izlaza." (studentica njemačkog i sociologije)

Također, u odgovorima zamjetan je motiv „neizbježnosti“ prema kojem lijenost čini integralni dio ljudske prirode $s$ kojim se svi suočavamo $s$ većim ili manjim uspjehom. Dio sugovornika/ca naveo je pak specifičnije uzroke nastanka lijenosti:

„Lijenost može nastati iz više razloga. Osoba može biti lijena kod mentalnog rada jer joj posao koji odraduje nije dovoljno zanimljiv ili u slučaju fizičkog posla jer želi izbjeći fizički napor." (student povijesti i njemačkog)

Razvidno je, dakle, da su naši/e sugovornici/e ukazivali/e na širok dijapazon manifestacija lijenosti. Isto tako, valja primijetiti da je dio sugovornika/ca odgovor na odgovarajući upit interpretirao više u kauzalnim terminima, dakle, ukazivanjem na neposredne uzroke lijenosti (primjerice, napor stvara lijenost kao kontra-reakciju), dok su se drugi više referirali na generičko-longitudinalne aspekte (gdje se lijenost poima kao ishod navika stečenih kroz duže vrijeme).

„Znam da moja lijenost izlazi na vidjelo ili kad moram napravit' stvar koja me ne zanima ili kad želim napravit' stvar koja me jako zanima. Ako me nešto ne zanima, onda nemam motivacije da to radim pa odgadam. S druge strane, ako mi se nešto čini važnim, onda se uključi neki latentni perfekcionizam, pa analiziram stvar do besvijesti jer ju želim izvest najsavršenije ikad. "(studentica anglistike i komparativne književnosti)

Ranije smo naveli da je prividna lijenost često motivacijski problem. Eksterni društveni utjecaji impostiraju diferentne obaveze, a ako njihova vrijednost nije internalizirana kod pojedinca, nastupa situacija u kojoj je pojedinac primoran motivirati se za izvršenje zadatka i u slučaju da za time nije prisutan interes. $S$ druge strane, aktivnosti kojima pridaje visok rang značaja također mogu djelovati inhibirajuće ponajprije u vidu perfekcionizma koji nerijetko implicira strah od neuspjeha. Ta je bojazan prisutna na mikroplanu, u kojem osobe iz neposredne okoline upoznate s nečijom internom hijerarhijom vrijednosti, ciljeva i ambicija gaje izvjesna očekivanja štoviše i stvaraju pritisak postizanja uspjeha. Isti je pritisak također prisutan i na makro razini, u širim društvenim okvirima aktualnoga neoliberalnog društvenog poretka koji u svojom normativno-vrijednosnoj komponenti priznaje isključivo uspjeh.

Jedna sugovornica navela je da se lijenost razvija u slučaju dugotrajnog rada koji se ne smatra korisnim ili pak ako rad implicira osjećaj iscrpljenosti:

„Ili nakon nekog razdoblja produktivnosti jednostavno se iscrpi sva snaga i volja, ili s druge strane, ako netko dugo ne radi ništa zbog čega se osjeća korisno jednostavno ga ponese taj osjećaj nerada koji dovodi do lijenosti." (studentica španjolskog i sociologije)

Osjećaj lijenosti može se razviti u situaciji gdje je rad pojedinca otuđen od rezultata tog rada, odnosno kada pojedinac ne vidi njegovu intrinzičnu vrijednost, već tek dobiva sredstva koja mu omogućuju pristup tržištu roba, odnosno konzumaciju određenih proizvoda.

Gotovo svi/e sugovornici/e smatraju da je lijenost jednim dijelom dispozicijska osobina, a djelomično plod utjecaja okoline, uglavnom ne dajući primat jednim od dvaju 
eksplanativnih faktora. Različiti su bili akcenti na to kako okolina utječe na razvijanje lijenosti: neki su smatrali da je najvažniji utjecaj roditelja, a drugi da cjelokupna okolina može dati impuls za razvoj lijenosti. Zamjetan je dio odgovora u kojoj se utjecaj roditelja ali i efekti čitave okoline mogu smatrati podjednako odgovornim za formiranjem lijene osobe. Sugovornici/e koji su pak smatrali/e da je lijenost urođena naprosto bi tek konstatirali/e da je netko po prirodi takav.

Većina sugovornika/ca koji/e bi se sjetili/e da su im roditelji rekli da su lijeni/e navela je sličan kontekst: školske obaveze i kućanske poslove. Pojam „lijenosti“ bi se najčešće koristio kao svojevrsna opomena za poticanje na veće zalaganje u školi ili kao mehanizam primoravanja za obavljanje određenih kućanskih poslova. Nekoliko je sugovornika/ca uspjelo evocirati i rekonstruirati svoja osjećanja u takvim situacijama:

„Da me ne razumiju, ne znam bilo mi je ono... Jer ja se nisam nužno osjećala lijeno, ja sam htjela raditi sve te stvari ali ono, ne da mi se. Ne znam." (studentica sociologije)

„Osjećala bih se uvrijedeno, zato što to nije istina i zato što, ukoliko ja dobijem neku zapovijed ne znaci da ja to moram instant obaviti, jer to jednostavno nije nekakav refleks nije nekakav podražaj. Neki ljudi jednostavno to brže percipiraju neki sporije. Mislim da to roditelji i ljudi u obrazovnom sustavu moraju poštovat." "(studentica njemačkog i sociologije)

Sugovornice su u ovim primjerima navele da su ih roditelji krivo shvatili, što ukazuje na kompleksnost upotrebe pojma. Lijenost se može olako koristiti kao motivacijska opomena, ali neko ponašanje koje se prividno može činiti lijenim uopće ne mora biti takvo. Sugovornike/ce smo pitali i o njihovim iskustvima odnosa s profesorima u školama po pitanju lijenosti. Odgovori su reflektirali sličan obrazac: nastavnici/e su u pravilu rijetko ili nikad individualno prozivali/e učenike i nazivali/e ih lijenima, ali su znali/e generalno upozoravati cijeli razred da ne budu lijeni i poticati ih da se trude.

„Pa da recimo općenito neke prijetnje kao da lijenošću ništa ne postižemo, da ne smijemo biti lijeni, da ovo da ono, da smo svi mi pametni, ali da nas lijenost samo sprječava. Klasični profesor." (studentica sociologije i pedagogije)

Slično kao i u slučaju roditelja, lijenost se upotrebljava kao opomena u svrhu motiviranja učenika, što nailazi na plodno tlo jer se radišnost apostrofira kao jedna od dominantnih društvenih vrijednosti. Također, škole kao društvene institucije imaju načelnu obvezu stvoriti produktivne građane, a negativno vrednovanje lijenosti dio je strategije za ostvarivanje tog cilja.

Među sugovornicima/ama s radnim iskustvom mogli su se uočiti slični motivi. Većina poslodavaca bi organizaciju određenih vremenskih parametara (poput frekventnosti i duljine stanki, mogućnost korištenja zahoda i sl.) isticala usmeno. Također bi se zabranjivali ili ograničavali razni tipovi aktivnosti:

„Ponekad bi netko od radnika napomenuo da treba raditi brže ili bi ogovarali nekoga tko je spor i ne da mu se raditi. Recimo, ne bi smjeli baš pričati izmedu stolova, dovikivati se jer to ometa rad, ili slušati muziku na sluśalice i slično." (studentica lingvistike i francuskog) „Postavili su neka osnovna pravila ponašanja, izmedu ostalog zabranjivanjem i ograničavanjem aktivnosti koje bi potencijalno mogle ometati rad. "(student pedagogije i sociologije) 
Ograničenja uglavnom možemo protumačiti kao želju poslodavca da balansira korist deriviranu iz rada svojih zaposlenika s njihovim potrebama i željom za ugodnom radnom atmosferom. ${ }^{19}$ Sugovornike/ce smo upitali jesu li dobili/e pisani materijal koji definira odnosno kodificira pravila ponašanja i / ili radne navike i vrijednosti.

„Zna se da se neke stvari ne smiju napraviti, al' nisu mi morali to posebno govoriti, jer ne bih to išao raditi nikad." (student arheologije i etnologije)

Ova izjava upućuje na generalnu poslovnu kulturu koja se može interpretirati kao dio širih društvenih normi pristojnog ponašanja. Na tom je tragu još nekoliko aktera isticalo maksime da nije dobro kasniti na posao, pretjerano upotrebljavati mobilne telefone ili manifestirati srodne manire. Bilo je i iznimaka gdje su sugovornici/e zaprimili/e pisani materijal o pravilima ponašanja:

„Pa, prvo je išlo usmeno ali onda kada su vidjeli da s dosta ljudi postoje problemi onda je to došlo i napismeno." (studentica pedagogije i sociologije)

U ovome slučaju, kodificiranje pravila ponašanja je upotrijebljeno kao sredstvo snažnije kontrole i prisile zaposlenika. To što su poslodavci upotrijebili ovu metodu nakon pojave izvjesnih „poteškoća“ ukazuje na mentalitet da ako je nešto zapisano, onda to nosi veću težinu i postaje obligatorno. Također, jedna je sugovornica dobila specifične naputke o pravilu ponašanja, jer je radila kao animatorica, što je za očekivati budući se $\mathrm{u}$ tome poslu često radi s djecom pa je potrebno uspostaviti jasna pravila ponašanja zbog njihove sigurnosti.

Interesantno, većinu su sugovornika/ca za vrijeme razgovora za posao ispitali o navikama i hobijima, ali poslodavac, barem ne eksplicitno pred njima, nikad nije vrednovao navike i hobije. Možemo samo pretpostaviti odakle interes poslodavaca za ovaj tip aktivnosti: bavljenje sportom može indicirati određenu samodisciplinu, a upražnjavanje određenih hobija potencijalnu kreativnost koja se može reflektirati na ukupnu radnu učinkovitost.

Zanimalo nas je i kako naši/e sugovornici/e vide odnos između organiziranih svjetskih religija i lijenosti, s posebnim osvrtom na kršćanstvo, budući da je riječ o društvenoj sredini u kojoj se stanovništvo dominantno izjašnjava katolicima.

„Pa, lijenost je jedan od sedam smrtnih grijeha, to valjda dovoljno govori o mišljenju katoličke Crkve. Marljivost i disciplina jesu tradicionalne vrijednosti vecine kultura, pa vjerojatno ni s ostalim organiziranim religijama nije drukčije. "(studentica anglistike i komparativne književnosti)

Šestero je naših sugovornika/ca, kada ih se pitalo koji je odnos svjetskih religija prema lijenosti, navelo kako je lijenost smrtni grijeh u kršćanstvu. Dio tih sugovornika/ca sjetio se konkretnih propovijedi svećenika u crkvi u kojima se lijenost osuđivala i pozivalo se na marljivost:

19 K tome, dakako, postoje i legislativne odredbe koji poslodavca obvezuju na poštivanje prava zaposlenika. 
„Pričali su nam na pričesti i časne kak’ ne treba biti lijen, svi neki važniji likovi u Bibliji su bili tesari ili slični majstori, uvijek vrijedni i marljivi, pa su tako i nama govorili da treba bit' marljiv i vrijedan, odabrat' teži put, a ne se samo provlačit' i slično." (student sociologije)

„Ovisi o čemu je evandelje, ali... Ako je neko posebno radno onda spomenu. Ako imate slobodnog vremena, ne tratite ga, ne prepustajte se napastima. "(studentica anglistike i komparativne književnosti)

Decidirane odgovore po pitanju njihovih spoznaja kako je lijenost tretirana u drugim religijama, zbog nedostatne informiranosti sugovornika/ca, nismo zaprimili, premda je uvriježeno mišljenje da je sve religije negativno sagledavaju.

Sljedeći tematski blok odnosio se na inklinaciju prema prokrastinaciji. Osim dvoje naših sugovornika/ca (koji/e ističu da u pravilu obveze obavljaju čim ranije), svi/e su izjavili/e da teže odgađanju izvršenja obveza te radije obavljaju bilo što osim pred njih postavljenoga obligatornog zadatka:

„Bilo kojim drugim aktivnostima, najčš́će neš jako glupo i kaj nema koristi." (student sociologije)

„Sve, znači ono buljila bih u zid ako treba."(studentica njemačkog i sociologije)

„Generalno, bavila bih se svim drugim aktivnostima samo ne tim. To može biti najbanalnija stvar od gledanja serije, inače ne gledam puno serije ali kad imam puno obaveza onda mi baš od jednom padne na pamet. "(studentica njemačkog i sociologije)

Ovo nam ukazuje na univerzalnost prokrastinacije, ali teško je odrediti njezin intenzitet. ${ }^{20}$ Podosta je naših sugovornika/ca akcentiralo da prokrastinacija zavisi o vremenskom faktoru:

„Ovisi koji zadatak i kako se osjećam u tom trenutku. “(studentica francuskog i lingvistike) „Ovisi koji je zadatak i koliko je hitan. “(studentica anglistike i komparativne književnosti) Zasigurno je jednostavnije prepustiti se nagonima i željama koje je lako instantno ispuniti, ako je potreba za završavanjem nekog zadatka (prividno) daleka. Čini se da naši/e sugovornici/e vrše kalkulacije o vremenskom ulogu zadatka i očekivanoj količini truda potrebnoj za njegovo izvršenje. Izgledno je to dio procesa racionalizacije odluke za odgađanjem zadatka, što može biti dio taktike za umanjenjem nelagode povezane $s$ odgodom:

„A kad odgadam, uvijek mi visi tu negdje u zraku taj osjećaj da to moram obaviti i ne mogu se potpuno opustiti, ali najčešce ne poduzimam ništa do krajnjeg trenutka ili zbog lijenosti ili zbog drugih obveza. "(studentica španjolskog i sociologije)

„Ovisi o zadatku, ak’ je neki bitan, onda me kopka, a inače koga briga."(student sociologije)

$20 \mathrm{U}$ tu bi svrhu trebalo poduzeti izvjesno longitudinalno istraživanje određenih oblika uobičajenih ponašanja na temelju opservacijskih zapažanja odnosno, drugih u većoj mjeri „objektivističkih“ metodoloških pristupa. 
Prisutnost negativnih emocija pri prokrastinaciji ukazuje na jačinu eksternih pritisaka na pojedince i jačinu internaliziranja društvenih normi i vrijednosti o radišnosti, odnosno kao efekt djelatnoga impostiranog samoregulativnog sustava individuuma.

Planiranje i kategoriziranje obaveza može biti i dio racionalnih strategija naših sugovornika/ca. Nekoliko je sugovornika/ca govorilo o fenomenu koji smo prethodno nazvali „dobrom prokrastinacijom“:

"Taj stres upotrijebim kao da me natjera da radim to. Kao da npr. nešto što se radi 2 mjeseca u 11 sati ono u komadu. Takva sam više... Ali ne bih rekla da je to lijeno, nego samo neodgovorno. Drugi ljudi će rasporediti isto vrijeme na kojem će raditi na nečemu kao u duži period, da to bude lijepo. A npr. ja il' netko drugi će sve napraviti odjednom." (studentica sociologije) Iako radni elan naše sugovornice biva zapodjenut iz negativne emocije stresa, ona ga uspijeva kanalizirati u pravcu uspješnog obavljanja postavljenog naloga. Ponovno, ističemo, iz jedne izjave ne možemo suditi o efikasnosti tog pristupa, ali indikativno je pojavljivanje ovog motiva.

Velik broj sugovornika/ca konzumirao je različiti medijski sadržaj prilikom odgode zadatka:

„Kad mi se nešto ne da napravit' onda isto si znam upalit' radio, to mi je na neki način distrakcija i ono, kao čujem neku dobru pjesmu i onda zaboravim na to što trebam napravit'. To, ili internet... da, to je, katastrofa, to bilo sta da radim ne mora uopće bit' nekakav sadržaj na internetu koji me interesira, a odvuče me u roku dvije sekunde. To, onda općenito svi komunikacijski kanali putem mobitela. "(studentica njemačkog i sociologije)

„Umjesto obavljanja obveza najčesće završim na internetu. Ako nadem nešto što me zanima, onda je grižnja savjesti slaba ili ne postoji. Ako završim na YouTubeu gledajuć videe s mačkama, onda je grižnja savjesti jača, iako ne znam kolko' je to zato što odgadam neku odredenu obvezu, a kolko' je zato sto nisam našla ništa pametnije za gledat." (studentica anglistike i komparativne književnosti)

Sveprisutnost medija u današnjem životu potiče njihovu konzumaciju, pa ne čudi da gotovo svim našim sugovornicima/ama konzumacija medija predstavlja velik dio dokolice, ali i aktivnost kojoj se pobjegne kada se želi odgoditi neki zadatak. Pitanje je, potiču li sami mediji svoju konzumaciju, odnosno koliko je to uopće voluntaristički čin? Je li ishod sveprisutnosti medija njihova neizbježna konzumacija?

Naši/e sugovornici/e dominantno ističu da mediji, kao važne sastavnice aktualne potrošačke kulture, potiču lijenosti i od nje profitiraju:

„Mediji definitivno potiču i profitiraju od lijenosti. Oni ne profitiraju nužno samo od lijenosti, oni profitiraju od osoba koje imaju slobodnog vremena poput starijih osoba i djece. Osobe s više slobodnog vremena najviše gledaju televiziju, čitaju novine i provode vrijeme na društvenim mrežama. Društvene mreže ovdje imaju posebnu prednost jer sadržajem obuhvaćaju puno širi raspon tema i interesa. " (student njemačkog i povijesti)

„Mediji profitiraju od lijenosti, jer nas sama lijenost tjera na to da gledamo medije." (student informacijskih znanosti) 
„Mediji profitiraju od lijenosti, jer nas odvraćaju od naših obaveza koje trebamo ispuniti." (student sociologije i antropologije)

Određena procijenjena atraktivnost medijskog sadržaja u odnosu na postavljene obaveze zasigurno potiče lijenost, odnosno prokrastiniranje, a kad je ta primamljivost sveprisutna i lako dostupna, poriv za prokrastinacijom je utoliko izgledniji. Tome pridonosi okolnost da konzumacija dobrog dijela medijskih sadržaja iziskuje minimalni napor te da su dizajnirani tako da se dožive instantno zabavnima i zanimljivima:

„Mediji profitiraju od lijenosti jer smo u odnosu s medijima u vé́oj mjeri mi pasivni sudionici. Sveprisutnost medija i njihov značaj u današnjem društvu sami po sebi potiču pasivnost, a time u neku ruku i lijenost." (student pedagogije i sociologije)

Obavljanje zadataka zahtijeva različite razine truda, pa je nešto naporno i zamorno lako zamijeniti nečim zabavnim. Također, aktivnosti koje nose visoku vrijednost, spram kojih se osjeća strast no iziskuju trud, a konačno zadovoljstvo pružaju tek nakon duljega perioda, lako je supstituirati medijskim sadržajem koji odmah implicira ugodu. U određenom smislu moglo bi se reći da je u interesu medija da pojedinci budu lijeni i da prokrastiniraju s obzirom da se tako pospješuje njihova konzumacija.

$S$ druge strane, postoje medijski sadržaji koji osuđuju lijenost ili pak promoviraju aktivni i zdravi životni stil (tjelovježbu i zdravu prehranu), ali naši/e sugovornici/e naglašavaju kako je to tek jedan dio medijskog spektra. Iako bi se stoga moglo reći da se mediji bave lijenošću, većina sugovornika/ca smatra da se lijenost zapravo eksplicitno i ne pojavljuje često u medijima, a još manje u smislu propitkivanja njezinog društvenog značaja.

Gotovo svi/e sugovornici/e složili/e su se da je lijenost raširena društvena pojava, ali prisutna su različita stanovišta o tome može li se okarakterizirati kao društveni problem:

„Da, jer je to dio ljudske osobnosti." (student antropologije i sociologije)

„O da, ljudska priroda. Nekad se nešto nekom ne da i to je to. "(student sociologije)

Gotovo svi/e sugovornici/e dali/e su obrazloženje da je lijenost raširena jer je jednostavno dio ljudske prirode. No, čak i u tom slučaju, razina i raširenost lijenosti predstavlja faktor koji određuje kada lijenost postaje društveni problem.

Drugi pak smatraju da je lijenost društveni problem koji se očituje na razne načine:

„Ne toliko u poslovnom svijetu, jer to ovisi za koga radiš i što, ali definitivno u obrazovanju... učenici sami sebi škode ako nešto ne rade." (studentica njemačkog i sociologije)

„Mislim da je raširena zato što se ona prvenstveno odražava na ljudsko zdravlje, što vidimo evidentno u broju pretilih ljudi općenito. Jer lijenost nije isključivo povezana sizvršenjem obaveza nego i sa samim pokretom, kretnjom... To vidimo kako se ljudi jednostavno ne kreću. Jedan od razloga može biti to što rade sjedilački posao, a drugi razlog može biti jednostavno ne kretanje, sjedenje doma i ne radenje ničeg. Mislim da se u broju tih pretilih ljudi odražava ta raširenost lijenosti. "(studentica njemačkog i sociologije)

Kada smo upitali naše sugovornike/ce ima li lijenost pozitivne aspekte većina ih se složila da postoje. Dvoje sugovornika/ca reklo je da ih nema: 
"Pa pozitivna funkcija bi bila da nas recimo dijeli od tog nekakvog robotskog obavljanja stvari i mehanizma nekakvog jednostavnog ponašanja na nekakav refleks. Da nas dijeli od robota. Da smo sposobni u svojoj glavi percipirat' to da nam se nešto jednostavno ne da." (studentica njemačkog i sociologije)

„Mislim da malo lijenosti dobro dođe, inače bi pregorili.“ (studentica španjolskog i sociologije)

„Mislim da bi poticanje lijenosti u blagoj mjeri pomoglo ljudima da se više opuste i budu mentalno zdraviji, ako previse rade. "(student informacijskih znanosti)

Pozitivna funkcija lijenosti koju su svi apostrofirali jest, dakle - odmor. Lijenost je preferirana u razumnim dozama, jer ljudi ne mogu neprestano raditi i biti maksimalno produktivni. No, pitanje je zašto naši/e sugovornici/e i takav odmak od uobičajenoga radnog ritma označuju lijenošću? Nije li to ispravnije jednostavno nazvati odmorom? Izgledno je to simptom duboko strukturno ukorijenjenog imperativa suvremenoga neoliberalnog okruženja koje neprekidno impostira zahtjev za efikasnošću, jer „vrijeme je novac" pa se svaka devijacija od te maksime tretira negativno u terminima lijenosti.

$\mathrm{Na}$ toj je liniji iznijet sljedeći iskaz prema kojem je važno poticati lijenost, jer se nalazimo u društvu koje previše naglašava produktivnost:

„Današnji svijet je „posložen" da ljudi i nemaju previše vremena za ljenčarenje, stoga ne smatram da lijenost u društvu treba smanjiti. Prosječan čovjek provede većinu svog života radeći jer prosječan životni stil i ne dopušta drugačije. Smatram da bi se lijenost kod ljudi trebala poticati do određene mjere jer lijenost u jednu ruku i pomaže u povećanju kvalitete života." (student njemačkog i povijesti)

Mišljenja su po pitanju potrebe za dokidanjem ili pak poticanja lijenosti vrlo podijeljena te pokrivaju raster od vrlo negativnog poimanja prema kojem bi lijenost trebalo suzbiti do točke koja smatra da je lijenost neophodna ponajprije jer otvara procjepe za odmak od tipične užurbanosti i pritiska aktualnoga neoliberalno-kapitalističkog okruženja. Zanimljiv je i sljedeći pogled na lijenost:

„Lijenost je raširen pojam $u$ društvu, po mom mišljenju lijenost ne postoji, ali pasivnost koja se često identificira kao lijenost je svakako raširena. Njenu funkciju možemo pronaći u održavanju postojećeg poretka i postojećih tendencija." (student pedagogije i sociologije)

Prema ovome pogledu, pasivnost pojedinaca nešto je što ide u prilog reprodukciji društvenog poretka s obzirom da ustezanje od propitivanja pa onda i pokušaja mijene aktualnog poretka moći indirektno znači održavanje statusa quo. ${ }^{21}$

Implicitno proizlazi da bi se pasivnost i lijenost pojedinaca smanjila pod pretpostavkom da je društvo slobodnije te da su institucije, norme i vrijednosti društva manje prisilne, kao što je razvidno iz zapisa jednoga našeg razgovora:

21 Time se otvara pitanje relacije apatije i lijenosti spram (ne)mogućnosti iniciranja društvene promjene što je tema koje se na ovome mjestu nećemo latiti. 
„Odmakom od postojeciih vrlo strukturiranih sustava poput na primjer školstva, odnosno njihovim restrukturiranjem i smanjenjem broja zahtjeva koje ti sustavi postavljaju pojedincu, bi mogli funkcionirati slobodnije te bi se mogli posvetiti stvarima za koje imamo motivaciju te bi se percepcija neaktivnosti koja se interpretira kao lijenost smanjila." (student pedagogije i sociologije)

Sugovornici/e koji/e su tražili/e načine kako reducirati lijenost ključ pronalaze u odgojnom sustavu:

„Mislim da bi se to moglo kroz sistem školovanja nekako odmah... jer to je jedan problem koji dolazi od malih nogu koji se počinje u ranom školskom dobu, i onda se razvija dalje ne znam na fakultetu, poslu itd. Tako da bi se to ajmo reć trebalo počet reformirat' u korijenu. " (studentica njemačkog i sociologije)

\section{RASPRAVA}

Unatoč limitiranim okvirima, u terminima veličine i prigodnosti uzorka te zbog naravi induktivno-eksplorativno, lokalno ukotvljenog istraživanja, koji nam stoga ne omogućuje bilo kakve generalizacije, ono nam daje višestruko interesantne uvide i naznačuje moguće daljnje istraživačke implikacije. $U$ određenom smislu, uvid u empiriju po pitanju tematiziranja lijenosti adekvatno reflektira širok obuhvat problematike $s$ kojom smo se suočili prilikom pokušaja konceptualnog određivanja predmeta. Naši/e su nam sugovornici/e ponudili/e raznolike definicije lijenosti koje supsumiraju diferentne dimenzije. Njihov raster seže od iskazivanja tvrdnje da je riječ o odrednici nečije psihološke konstitucije do ukazivanja da se pojedine ekspresije lijenosti formiraju unutar mreže društvenih faktora, odnosno strukturnih prisila nad pojedincem. Potonja je pozicija bitna potvrda naše središnje postavke da je riječ o eminentno društvenoj pojavi.

Zanimljiv je nalaz da se lijenost, napose prokrastinacija kao vid odgode izvršenja postavljene zadaće, detektira kao univerzalan element zastupljen u iskustvima svih sugovorni$\mathrm{ka} / \mathrm{ca}$ što upućuje na njezinu opću društvenu rasprostranjenost u okvirima suvremenoga hrvatskog društva. Tu je temporalnu i spacijalnu ukotvljenost lijenosti bitno apostrofirati jer se njome ukazuje na historicitet lijenosti koja ne postoji kao moguća antropološka ili ahistorijska konstanta već se pojavljuje kao odraz specifičnih socioekonomskih formacija i korespondentnih sociokulturnih matrica. Suvremeni globalni neoliberalni kapitalistički poredak kojeg je i hrvatsko društvo dio reprezentira podesan teren za empirijsko izučavanje lijenosti. ${ }^{22}$ Razvidno je da se radišnost iskazuje kao jedna od težišnih društvenih vrijednosti pa se indirektno lijenost razotkriva kao njezino naličje. Različite vrste dionika društvenog života sukreiraju averzivan stav spram lijenosti: od aktera iz

22 Što, dakako, nipošto ne implicira da lijenost nije moguće identificirati i u drugim historijskim poznatim tipovima društava. U kontekstu hrvatskog društva također bi bilo zanimljivo ispitati na koji se način lijenost tretirala u razdoblju socijalizma. 
obiteljskog okruženja, dionika odgojno-obrazovnog sustava, reprezentanta religijskih organizacija, do pretpostavljenih na radnom mjestu. Iako se narativi naznačenih aktera mogu ponešto razlikovati zajednička im je funkcija transmisija kulturnog koda koja difamira lijenost istodobno proklamirajući radišnost. U kontekstu odnošenja elemenata aktualnoga društvenog okruženja spram lijenosti izuzetno je zanimljiva pozicija medija koji su u tom smislu naglašeno ambivalentni: s jedne strane oni potvrđuju obrazac inzistiranja na kapitalističkoj logici samodiscipline, odgovornosti i radišnosti, $s$ druge pak suspendiraju isti taj princip propagirajući hedonizam tijesno isprepleten $s$ konzumerizmom odnosno potrošačkom kulturom. Dakako, potrošnja što roba što medijskih sadržaja može se upražnjavati tek onkraj rada i uz radne obaveze vezano samoodricanje, u životnim stilovima u kojima je jedan od dominantnih obrazaca - zabava. Indicirana je tenzija odnosno stanovito inherentno proturječje kapitalističkih narativa razvidno iz zaprimljenih odgovora. Na tom tragu, smatramo itekako uputnim, štoviše i važnim, dio budućih istraživanja lijenosti usmjeriti prema diskurzivnoj analizi diferentnih oblika medijskih sadržaja.

No, također se pokazuje da je konceptualno klupko povezano s izučavanjem lijenosti znatno zamršenije nego li se to na prvi pogled može poimati. Nije, naime, lako odijeliti pojam lijenosti od pojmova kao što su odmor ili dokolica s kojima stoji u određenoj tijesnoj relaciji. Teško je odrediti u kojem trenutku i prema kojim kriterijima odmor, kao oblik nužnog predaha i regeneracije od zamornosti rada, prerasta u lijenost? Iskazano u drugim kategorijama, pitanje je također prethodno razmatranog odnosa između slobodnog i radnog vremena koje se u današnje vrijeme sve više redefinira. Ne ulazeći u daljnja propitivanja, mišljenja smo da adekvatno konceptualiziranje pojma lijenosti i povezanih koncepata te njihovo empirijsko izučavanje može doprinijeti razumijevanju zamjetnog dijela aktualnih društvenih pojava i procesa.

\section{ZAKLJUČNO}

Smatramo da rad predstavlja iako malen, zapravo krucijalan korak prema sociologizaciji izučavanja lijenosti. Tome je doprinijela svojevrsna denaturalizacija koncepta gdje se nastojalo pokazati da lijenost nije nikakav imanentni atribut antropološke konstitucije, niti neminovno svojstvo nečijeg psihološkog ustrojstva. Nasuprot takvim stanovištima, pokazali smo da se lijenost ne može izučavati izolirano od sociokulturnog okruženja koji određen tip djelovanja etiketira takvim deskriptorom. Dublje ulaženje u materiju ukazuje na prisutnost ideje lijenosti u religijskim segmentima različitih sociokulturnih sklopova. Posebice je interesantna, i to je aspekt koji osobito podvlačimo, zastupljenost koncepta lijenosti u idejnoj matrici kapitalističke privrede. Moderni kapitalizam tako se pokazuje kao posebice podesno tlo za prezentnost i perzistentnost koncepta lijenosti. Štoviše, nije pogrešno reći da i danas predstavlja jedan od njegovih uporišnih stupova. Iz rakursa kapitalističke logike ideja lijenosti poima se u podvojenim terminima: eksplicitno negativno s obzirom da podriva zahtjev za odgovornošću i rigoroznošću, ali 
se implicitno potiče budući da se produkti kapitalističke privrede mogu konzumirati tek izvan sfere rada. Jedan od temeljnih doprinosa ovog priloga jest propozicija da je shvaćanje određenih praksi i narativa svojstvenih današnjim društvima moguće tek kroz izučavanje dubljih pozadinskih struktura i djelatnih mehanizama koji na sociokulturnoj i manifestnoj razini uopće produciraju ideju lijenosti. U tom smislu, sociološko istraživanje lijenosti zasigurno može pridonijeti boljem razumijevanju društvenog svijeta u kojem živimo. Iako nije ispostavio moguću jednoznačnu definiciju koncepta lijenosti, niti ponudio eventualne odgovore na nemali broj iznjedrenih pitanja, ovaj rad iscrtao je temeljne konture vrlo širokoga problemskog prostora koji iziskuje potpunije razmatranje.

\section{LITERATURA}

Andreou, C. (2007). Understanding Procrastination. Journal for the Theory of Social Behaviour, 37(2): 183-193.

Aristotel (prijevod Ross, W. D.) (1999). Nicomachean Ethics. Kitchener: Batoche Books. Ayyangar, T. R. Srinivasa (1938). The Yoga Upanisads. Madras: The Adyar Library.

Aronson, S. M. (2016). From the Shiftless Lazy to the Contemplative Scholars. Rhode Island Medical Journal, 99(1): 11-12.

Baudrillard, J. (1998). The Consumer Society: Mythsand Structures. London: Sage.

Bendassolli, P. F. (2013). Theory Building in Qualitative Research: Reconsidering the Problem of Induction. Qualitative Social Research, 14(1). DOI: 10.17169/fqs14.1.1851.

Birkelund, E. G. (2016). Rational Laziness - When Time is Limited, Supply Abundant and Decisions Have to Be Made. Analyse \& Kritik, 38(1): 203-225.

Bregman, R. (2016). Utopia for Realists: The Case for a Universal Basic Income, Open Borders, and a 15-hour Workweek. Amsterdam: The Correspondent.

Bröckling, U. (2016). The Entrepreneurial Self. London: SAGE Publications.

Carter, M. J. i Carter S. (2014). How Themes in Literature Can Inform Sociological Theory, Research and Teaching. The American Sociologist, 45(4): 388-411.

Choi, J. N. i Moran, S. V. (2009). Why Not Procrastinate? Development and Validation of a New Active Procrastination Scale. The Journal of Social Psychology, 149(2): $195-211$.

Chua, S. (2001). The sociology of leisure: anex amination of the relationship between perceived experience and leisure participation. Surrey: University of Surrey Library.

Cunliffe, J. i Erreygers, G. (ur.) (2004). The Origins of Universal Grants: An Anthology of Historical Writings on Basic Capital and Basic Income. London: Palgrave Macmillan.

Debord, G. (2014). The Society of the Spectacle. Berkeley: Bureau of Public Secrets.

Pirke Avot (Ethics of the Fathers). Chapter Two. Chabad-Lubavitch Media Center. URL: https://www.chabad.org/library/article_cdo/aid/2011/jewish/Chapter-Two. htm (21. 11.2019.) 
Ferrari, J. R. i Demir, B. U. O. A. (2009). Chronic Procrastination Among Turkish Adults: Exploring Decisional, Avoidant and Arousal Styles. The Journal of Social Psychology, 149(3): 302-307.

Foucault, M. (2016). Rođenje biopolitike. Zagreb: Sandorf \& Mizantrop.

Gilmore, L. i Boulton-Lewis, G. (2009). "Just Try Harder and You Will Shine": A Study of 20 Lazy Children. Australian Journal of Guidance and Counselling. 19(2): 95-103.

Haagh, L. (2019). The Case for the Case for Universal Basic Income. Cambridge: Polity Press.

Hammersley, M. (1995). Theory and Evidence in Qualitative Research. Quality \& Quantity, 29(1): 55-66.

Hewa, S. (1998). The Protestant Personality and Higher Education: American Philanthropy Beyond the "Progressive Era". International Journal of Politics, Culture and Society, 12(1): 135-163.

Kalanj, R. (1999). André Gorz: kraj rada i utopija postnajamnog društva. Socijalna ekologija, 8(3): 225-241.

Kosmas, J. M. (2003). The Roots of Procrastination: A Sociological Inquiry into Why I Wait Until Tomorrow. Human Architecture: Journal of the Sociology of Self-Knowledge, 2(2): 74-81.

LaMothe, R. (2006). Slothand Pastoral Counselling. Journal of Spirituality in Mental Health, 9(2): 3-24.

Lowrey, A. (2018). Give People Money: How a Universal Basic Income Would End Poverty, Revolutionize Work, and Remake the World. New York: Crown.

Marx, K. (1859). A Contribution to the Critique of Political Economy. Marxists Internet Archive. URL: https://www.marxists.org/archive/marx/works/1859/critique-poleconomy/ch01.htm\#2) (25.03.2020.)

Marx, K. (1867). Capital. Volume One. Marxists Internet Archive. URL: https://www. marxists.org/archive/marx/works/1867-c1/ch01.htm (04.04.2020.)

Matković, T. (2004). Nestajanje rada? Opseg i oblici zaposlenosti na početku informacijskoga doba. Društvena istraživanja: časopis za opća društvena pitanja, 13(1-2): 241-265.

Marshall, G. (2003). A Dictionary of Sociology. Oxford: Oxford University Press.

McCormack, T. (1971). Politics and Leisure. International Journal of Comparative Society, 12(3): 168-181.

Owens, S. G., Bowman, C. G. i Dill, C.A. (2008). Overcoming Procrastination: The Effect of Implementation Intentions. Journal of Applied Social Psychology, 38(2): 366-384.

Paić, Ž. (2013). Pitanje o prosvjetiteljstvu: Foucault i kritika modernosti. Studia lexicographica, 7(2): 181-211.

Pakholok, O. (2013). The Idea of Healthy Lifestyle and Its Transformation Into Health-Oriented Lifestyle in Contemporary Society. SAGE Open. DOI: 10.1177 $/ 2158244013500281$

Pelusi, N. (2007). The Lure of Laziness. Psychology Today, 40(4): 64-66. 
Poole, S. (2013). Why The Cult of Hard Work is Counter-Productive. New Statesman, 11.12.2013.URL: http://www.newstatesman.com/2013/12/right-be-lazy (10.08. 2017.)

Pychyl, T. A. (2008). Savouring the Flavours of Delay. English Studies in Canada, 34(23): $25-29$.

Reasinger, R. D. i Brownlow, S. (1996). Putting off Until Tomorrow What is Better Done Today: Academic Procrastination as a Function of Motivation Toward College Work. ERIC Document Reproduction Service, No. ED 401 81. Salisbury, NC: Catawba College.

Rota, E. (2012). The Worker and The Southerner: The Invention of Laziness and the Representation of Southern Europe in the Age of the Industrious Revolution. Cultural Critique, 82: 128-150.

Sahihal-Bukhari. Book of Invocations. Chapter: To seek refuge with Allah form cowardice and laziness, Vol. 8, Book 75, Hadith 380. URL: https://sunnah.com/ bukhari/80/66 (21.11.2019.)

Saldaña, J. (2009). The Coding Manual for Qualitative Researcher. Los Angeles, CA: Sage Publications.

Scollon, C. N. i King, L. A. (2004). Is the Good Life the Easy Life? Social Indicators Research, 68(2): 127-162.

Senécal, C., Koestner, R. i Vallerand, R. J. (1995). Self-Regulation and Academic Procrastination. The Journal of Social Psychology, 135(5): 607-619.

Smith, B. i Saelinger, D. (2015). Carl Knew He Had a Problem. Men's Health, 10(3): 101-104.

Standing, G. (2011). The Precariat. The New Dangerous Class. London: Bloomsbury Academic.

Szalavitz, M. (2003). Stand and Deliver. Psychology Today, 3(4): 50-54.

Thera, N. (ur.) (1994). The Five Mental Hindrances and Their Conquest. Selected Texts from the Pali Canon and the Commentaries. Access to Insight (BCBS Edition). URL: https://www.accesstoinsight.org/lib/authors/nyanaponika/wheel026.html\#sloth (21.11.2019.)

Weber, M. (2006). Protestantska etika i duh kapitalizma. Odnos izmedu religije i ekonomskog i društvenog života u modernoj kulturi. Zagreb: Misl.

Wehner, B. (2019). Universal Basic Income and the Reshaping of Democracy: Towards a Citizens' Stipend in a New Political Order. Cham: Springer International Publishing. 


\title{
TOWARDS THE SOCIOLOGIZATION OF LAZINESS - CONCEPTUAL CLARIFICATIONS AND PRELIMINARY EMPIRICAL INSIGHTS
}

\author{
Luka Canjek and Krešimir Žažar
}

\begin{abstract}
The basic intention of this paper is to examine "laziness" as an essentially social phenomenon. Laziness is generally considered to be an attribute of a person as an individual and is, as such, discussed in psychology and medical science primarily through the concept of procrastination. The main argument developed in this article is that laziness is an inherently social phenomenon, because its definition and, consequently, the categorization of an individual as "lazy", also depends on the socio-cultural context, which places the label of laziness on a particular form of individual's social action, i.e. lack thereof, while at the same time implying predominantly negative connotations. In this paper, the cultural background of defining laziness is present$e d$, by looking at its religious roots and the relation between the concept of laziness and a particular perception of time. Particular focus is placed on capitalist societies, whose socio-cultural matrix has proven to be suitable for categorizing certain behaviours as lazy. The relation of media and specific lifestyles toward the category of laziness is also problematized. On the conceptual level, the relationship between the concepts of laziness and procrastination, on the one side, but also of laziness and leisure, on the other side, is dissolved. In the second part of the paper, the results of empirical research are presented. The research was conducted in 2018 using semi-structured interviews on a convenient sample $(N=15)$ of male and female students at the Faculty of Humanities and Social Sciences of the University of Zagreb. Despite some epistemological limitations, the research findings indicate different notions on the aspects and dimensions of laziness among interviewed students, representing a robust basis for further necessary and detailed (theoretical and empirical) sociological research of this important socio-cultural phenomenon.
\end{abstract}

Key words: laziness, sociological approach, socio-cultural matrix, modern capitalist societies, media impact

\section{ZUR SOZIOLOGISIERUNG DER FAULHEIT - KONZEPTUELLE KLARIFIKATIONEN UND PRELIMINÄRE EMPIRISCHE EINSICHTEN}

\section{Zusammenfassung}

Luka Canjek und Krešimir Žažar

Die Grundabsicht dieser Arbeit ist, die „Faulheit" als ein essentielles Gesellschaftsphänomen zu problematisieren. Die Faulheit hält man gewöhnlich für ein Attribut eines Einzelnen und es wird durch das Prokrastinationskonzept, vor allem im Rahmen der Psychologie und der medizinschen Wissenschaft, thematisiert. Ein wesentlicher Standpunkt, den wir uns im Artikel zu bearbeiten bemühen, ist, dass die Faulheit eine der Gesellschaft inhärente Erscheinung ist, denn ihre Definition und demzufolge Kategorisierung eines bestimmten Individuums als "faul" hängt vom soziokulturellen Kontext ab, der eine bestimmte Form der sozialen Aktivität, präziser gesagt deren Fehlen, als Faulheit bezeichnet und dabei vorwiegend negative Konnotationen äußert. In der Arbeit wird auf den soziokulturellen Hintergrund der Definition von Faulheit hingewiesen, wobei ihre auf Religion beruhenden Wurzeln, sowie die Verbindung des Faulheitskonzepts mit dem spezifischen Verständnis der Zeit hervorgehoben werden. Insbesondere wird der Konzept der modernen kapitalistischen Gesellschaften problematisiert, deren Kulturmatrix sich zur Kategorisierung eines bestimmten Verhaltens als faul eignet, sowie das Verhältnis von Medien und des spezifischen Lebensstils der Kategorie der Faulheit gegenüber. Auf der konzeptuellen Ebene entwirrt sich das Verhältnis zwischen den Konzepten der Faulheit und der Prokrastination einerseits, aber auch Faulheit gegenüber Muße andererseits. 
Soc. ekol. Zagreb, Vol. 29 (2020.), No. 1

L. Canjek i K. Žažar: Prema sociologizaciji lijenosti - konceptualne klarifikacije i preliminarni empirijski uvidi

Im zweiten, empirischen teil der Arbeit geben wir einen Überblick der explorativen Untersuchung, die 2018 mittels Methode des halbstrukturierten Interviews am passenden Muster (N=15) von Studenten I Studentinnen der Philosphischen Fakultät der Universität Zagreb durchgeführt wurde. Trotz gewissen epistemologischen Einschränkungen, weisen die Ergebnisse der Untersuchung auf das Begreifen verschiedener Aspekte und Dimensionen der Faulheit in der Zielpopulation hin und das repräsentiert eine solide Basis für eine weitere nötige detailliertere Forschung dieses relevanten soziokuturellen Phänomens.

Schlüsselwörter: Konzept der Faulheit, soziologischer Ansatz, soziokulturelle Matrix, moderne kapitalistische Gesellschaften, Einfluss der Medien 